\title{
Cochrane
}

Library

Cochrane Database of Systematic Reviews

\section{Specialist home-based nursing services for children with acute and chronic illnesses (Review)}

Parab CS, Cooper C, Woolfenden S, Piper SM

Parab CS, Cooper C, Woolfenden S, Piper SM.

Specialist home-based nursing services for children with acute and chronic illnesses.

Cochrane Database of Systematic Reviews 2013, Issue 6. Art. No.: CD004383.

DOI: 10.1002/14651858.CD004383.pub3.

www.cochranelibrary.com 
TABLE OF CONTENTS

ABSTRACT

PLAIN LANGUAGE SUMMARY

BACKGROUND

OBJECTIVES

METHODS

RESULTS

Figure 1.

Figure 2.

Figure 3.

Figure 4.

DISCUSSION

AUTHORS' CONCLUSIONS

ACKNOWLEDGEMENTS

REFERENCES

CHARACTERISTICS OF STUDIES

ADDITIONAL TABLES

APPENDICES

WHAT'S NEW

HISTORY

CONTRIBUTIONS OF AUTHORS

DECLARATIONS OF INTEREST

INDEX TERMS 
[Intervention Review]

\title{
Specialist home-based nursing services for children with acute and chronic illnesses
}

\author{
Chitra S Parab¹, Carolyn Cooper², Susan Woolfenden ${ }^{3}$, Susan M Piper ${ }^{4}$
}

1/llawarra Shoalhaven Diagnostic \& Assessment Service, Illawarra Shoalhaven Local Health District, North Wollongong, Australia.

2Level 5 Douglas Building, Royal North Shore Hospital, St Leonards, Australia. ${ }^{3}$ Sydney Children's Hospitals Network, Sydney Children's Community Health Centre, Randwick, Australia. ${ }^{4}$ Department of Paediatrics, Wollongong Hospital, Illawarra Shoalhaven Local Health District, Wollongong, Australia

Contact: Chitra S Parab, Illawarra Shoalhaven Diagnostic \& Assessment Service, Illawarra Shoalhaven Local Health District, Porter Street Centre, 42A Porter Street, North Wollongong, NSW, 2500, Australia.Chitra.Parab@sesiahs.health.nsw.gov.au.

Editorial group: Cochrane Developmental, Psychosocial and Learning Problems Group.

Publication status and date: New search for studies and content updated (conclusions changed), published in Issue 6, 2013.

Citation: Parab CS, Cooper C, Woolfenden S, Piper SM. Specialist home-based nursing services for children with acute and chronic illnesses. Cochrane Database of Systematic Reviews 2013, Issue 6. Art. No.: CD004383. DOI: 10.1002/14651858.CD004383.pub3.

Copyright $(2013$ The Cochrane Collaboration. Published by John Wiley \& Sons, Ltd.

\section{A B S T R A C T}

\section{Background}

Specialist paediatric home-based nursing services have been proposed as a cost-effective means of reducing distress resulting from hospital admissions, while enhancing primary care and reducing length of hospital stay. This review is an update of our original review, which was published in 2006.

\section{Objectives}

To evaluate specialist home-based nursing services for children with acute and chronic illnesses.

\section{Search methods}

We searched the following databases in February 2012: the Cochrane Central Register of Controlled Trials (CENTRAL) in The Cochrane Library 2012 Issue 2, Ovid MEDLINE, EMBASE, PsycINFO, CINAHL and Sociological Abstracts. We also searched ClinicalTrials.gov and the WHO International Clinical Trials Registry Platform. No language restrictions were applied.

\section{Selection criteria}

Randomised controlled trials (RCTs) of children from birth to age 18 years with acute or chronic illnesses allocated to specialist homebased nursing services compared with conventional health care. Outcomes included utilisation of health care, physical and mental health, satisfaction, adverse health outcomes and costs.

\section{Data collection and analysis}

Two review authors extracted data from the studies independently and resolved any discrepancies by recourse to a third author. Metaanalysis was not appropriate because of the clinical diversity of the studies and the lack of common outcome measures.

\section{Main results}

We screened 4226 titles to yield seven RCTs with a total of 840 participants. Participants, interventions and outcomes were diverse. No significant differences were reported in health outcomes; two studies reported a reduction in the hospital stay with no difference in the hospital readmission rates. Three studies reported a reduction in parental anxiety and improvement in child behaviours was reported in three studies. Overall increased parental satisfaction was reported in three studies. Also, better parental coping and family functioning was reported in one study. By contrast, one study each reported no impact on parental burden of care or on functional status of children. Home 
care was reported as more costly for service providers with substantial cost savings for the family in two studies, while one study revealed no significant cost benefits for the family.

\section{Authors' conclusions}

Current research does not provide supporting evidence for a reduction in access to hospital services or a reduction in hospital readmission rate for children with acute and chronic illnesses using specialist home-based nursing services; however, the only summary finding across a few studies was that there is a significant decrease in length of hospitalisation. The preliminary results show no adverse impact on physical health outcomes and a number of papers reported improved satisfaction with home-based care. Further trials are required, measuring health, satisfaction, service utilisation and long-term costs.

\section{PLAIN LANGUAGE SUMMARY}

\section{Specialist home-based nursing services for children with acute and chronic illnesses}

This review aimed to examine whether specialist paediatric home-based nursing services for children with acute and chronic illnesses reduce the number of hospital admissions and length of stay, enhance health care in the community and reduce stress for families at the time of their child's illness. It is an update of our original review published in 2006 . We found seven relevant randomised controlled trials (RCTs) of total of 840 children aged from birth to 18 years with acute and/or chronic illnesses receiving either specialist home-based nursing services or conventional health care. The outcomes included use of health care services, physical and mental health, satisfaction, adverse health outcomes and costs. We decided not to combine the results of these RCTs because of the variety in types of services provided, types of participants and the outcome measures used. The results of individual RCTs show improved satisfaction with home-based care with no adverse impact on physical health outcomes for children. There is some evidence that specialist home-based nursing services reduce the length of hospital stay; however, there is no evidence that it leads to a reduction in use of hospital services. Further trials are required, measuring health, satisfaction, service use and long-term costs. 


\section{B A C K G R O U N D}

\section{Description of the condition}

The illness of a child leading to hospitalisation is a stressful event for the family (Kai 1996). It can be distressing for children, as in some emergency departments they may be separated from their families and the security of their own home (Farquahar 1990; Lenihan 1985). While not every child who presents to a hospital is admitted (Cooper 2000), many such children spend several hours in the emergency department (ED) while being observed or assessed (Browne 1996); in addition, children may wait while their carers are provided with education on how to manage the child's illness.

Children presenting at EDs frequently have a non-urgent problem (Bowling 1987; Halfon 1996; Jones 1999; Worsley 1985) and no usual care provider (Beebe 1993; Grover 1994). Many parents take their child to an ED seeking reassurance (Boyle 2000). These presentations, and subsequent admissions, may provide opportunities to give carers the confidence to support and care for their child, as well as to provide education about the disease process and its management. Admission of children is not always determined by the severity of their illness; it can also be influenced by previous medical consultations for the illness as well as parental expectations that the child will not be discharged from the ED (Cooper 2003).

In the current era, the necessity to explore alternative models of service delivery such as home-based nursing services has become more important, based on increasing survival of children with complex conditions, and also as it has become more feasible to provide high-technology interventions at home (Parker 2012). Thus, there is a shift towards parents being more responsible for complex care for children children with chronic illnesses in the home settings with educational as well as clinical management support.

\section{Description of the intervention}

The need to reduce hospital admission rates and shorten the length of hospital stay has prompted the development of specialist homebased nursing services for children with acute and chronic illnesses. The home-based nursing care substitutes for acute hospital review and/or admission by providing clinical review, support, education and management of the acutely or chronically unwell child in their own home. If the child requires it, they are provided with streamlined access to hospital services. It has been postulated that these services have the potential to reduce the number of hospital admissions (Meates 1997; Smith 1986), to reduce the length of stay (Meates 1997; Whiting 1997) and to facilitate early discharge by providing a continuum of care from the hospital into the home (Meates 1997). They also provide opportunities to enhance primary care in the community through liaison with general practitioners (GPs) and through links with other community-based health services (Fradd 1994).

\section{Why it is important to do this review}

The development of specialist home-based nursing services for children with acute and chronic illnesses has been determined by local circumstance and enthusiastic individuals rather than strategic planning based on evidence (While 2000), resulting in a diverse range of service models. Much of the literature comprises accounts of service development (Box 1993) or descriptive studies of parent or professional views (Madigan 1997; Sartain 2001). Literature related to the safety of models of care is limited (McConnochie 1998; Montalto 1998) and concerns are rapidly increasing about the impact of changes in delivery and financing mechanisms on quality of care (Kelly 1994). Empirical data are needed about the effects of specialist home-based nursing services for children with acute and chronic illnesses, to explore the strengths and weaknesses of different service models, as well as general efficacy.

The literature search for this review was completed in 2005 prior to its first publication (Cooper 2006). Subsequently, a systematic review was published in the UK about international evidence for the effectiveness and costs of paediatric home care. The Parker 2012 review was produced because there had not been a substantial growth in this kind of service despite advocacy by policy makers and professionals over the past few decades. We have conducted this update on a similar basis, to explore the available international evidence regarding specialist home-based nursing services for children and adolescents.

\section{O B J E C T IVES}

To evaluate the impact of specialist home-based nursing services for children with acute and chronic illnesses.

\section{METHODS}

\section{Criteria for considering studies for this review}

\section{Types of studies}

Trials were eligible for inclusion in the review if:

1. The assignment of study participants to the intervention or control group was random or quasi-random, for example, by alternate allocation;

2. The study intervention had paediatric nursing outreach services as its major focus;

3. There was at least one objective measure, for example, hospital admission data and/or a standardised measure such as a behaviour checklist, and that such measures were used for both intervention and control groups.

\section{Types of participants}

Children aged from birth to 18 years with acute and or chronic illnesses. In this review, terms such as 'chronic illness' and 'longterm illness' are used interchangeably.

\section{Types of interventions}

Specialist home-based nursing services provided to children with acute illnesses and/or chronic and complex conditions, compared with conventional health care (for example, hospital admission) as the control group. We excluded studies where nurses provided planned illness educational support independent of clinical review and management of children with acute and/or chronic diseases.

\section{Types of outcome measures}

1. Physical health of participants;

2. Mental health of participants;

3. Utilisation of emergency departments (EDs);

4. Hospital admissions; 
5. Length of stay in hospital;

6. Parental, child and referrer satisfaction;

7. Quality of life of children and their carers;

8. Cost of treatment for the family and to the service providers.

The study outcomes were measured using the following.

1. Hospital data on service utilisation, admissions, length of stay.

2. Questionnaires, for example, quality of life questionnaires, health outcome rating scales.

3. Satisfaction surveys.

\section{Search methods for identification of studies}

\section{Electronic searches}

This update is based on database searches run in February 2012 (Appendix 1), which cover the period since the search date of the previous version of this review in August 2005. We used the most recent version of the Cochrane highly sensitive search strategy for identifying randomised trials in Ovid MEDLINE (Lefebvre 2008) and searched two additional sources (ClinicalTrials.gov and International Clinical Trials Registry Platform).

We searched the following databases with no language restrictions.

The Cochrane Central Register of Controlled Trials (CENTRAL), part of the The Cochrane Library, 2012 Issue 2, last searched 9 February 2012;

Ovid MEDLINE (1946 to January Week 4 2012), last searched 8 February 2012;

CINAHL (1937 to current), last searched 9 February 2012;

EMBASE (1980 to 2012 Week 05), last searched 9 February 2012

PsycINFO (1806 to Feb Week 12012 ), last searched 9 February 2012;

Sociological Abstracts (Sociofile) (1952 to current), last searched 9

February 2012;

ClinicalTrials.gov, all available years searched 10 February 2012; International Clinical Trials Registry Platform, all available years searched 10 February 2012.

\section{Searching other resources}

The archives of abstracts from the Pediatric Academic Societies (incorporating the American Ambulatory Pediatric Association and the Society for Pediatric Research) Annual Scientific Meetings from 2000 to 2012 did not yield any unpublished data from randomised trials evaluating specialist home-based nursing services for children. We had no responses to emails to the Ambulatory Care Australia email list and the 'Hospital in the Home' electronic exchange.

\section{Data collection and analysis}

\section{Selection of studies}

Three review authors working independently (CC, DW, SW) screened titles and abstracts from the searches for the original review and two authors (CP, CC) screened results for this update. We resolved disagreements by consensus. We obtained potentially relevant articles for assessment of the full text and for data extraction.

\section{Data extraction and management}

We input data using Review Manager 5.1 (Cochrane Handbook). Data extraction forms were developed a priori and included information about study location, methods, participants, type of ambulatory paediatric intervention, and outcomes. Two review authors (CC, SW) independently performed data extraction for the initial phase of the review and two (CP, CC) for the next phase. We resolved disagreements by negotiation with a third review author (DW for the first phase and SW for the second phase).

\section{Assessment of risk of bias in included studies}

We assessed the risk of bias for the five previously included studies and the two newly added studies using the domain-based evaluation tool described in the Cochrane Handbook. Each study was assessed as being at low, high or unclear risk of bias for allocation concealment, blinding, incomplete outcome data and other sources of bias.

\section{Measures of treatment effect}

We report mean differences and 95\% confidence intervals for continuous variables, where they were available. For binary outcomes, we report the risk ratio and 95\% confidence interval. For meta-analysis, where possible in future updates, we will use mean differences for continuous variables, with standardised mean differences if different scales measure the same construct in different studies, and risk ratios for binary outcomes.

\section{Dealing with missing data}

We analysed data where possible on an intention-to-treat basis, i.e. with all participants randomised in their original groups. We contacted trial authors to obtain missing or additional information.

\section{Assessment of reporting biases}

The tool described in the Cochrane Handbook was used to assess the risk of bias in included studies. Two authors (CP, $\mathrm{CC}$ ) independently carried out this assessment and there was an agreement among both for conclusions.

\section{Data synthesis}

Due to the clinical diversity of the participants' illnesses and the services offered, as well as a lack of common outcome measures, we decided against meta-analysis and statistical assessment of heterogeneity (the $I^{2}$ statistic; Higgins 2002), and we therefore provide a narrative summary. In future updates, we intend to include any available data in meta-analyses if it proves feasible.

\section{Subgroup analysis and investigation of heterogeneity}

We stratified the results to determine any differences in treatment effects according to age and type of intervention:

1. Clinically different interventions, for example, hospital-based versus community-based services;

2. Clinically relevant differences between groups of participants:

- children with acute illness, children with chronic illness, children with chronic haematological illnesses;

- children under 10 years, children between 10 and 18 years. 
We present results according to the above subgroups. However statistical subgroup analysis was not possible for the current version of this review.

\section{Sensitivity analysis}

Sensitivity analysis (to evaluate the impact of study quality on outcome) was not possible. If a meta-analysis can be undertaken in future updates, we will use sensitivity analyses to determine the impact of risk of bias on our findings.

\section{RES U L T S}

\section{Description of studies}

\section{Results of the search}

The original review included five studies. The search was run again from August 2005 until February 2012. A total of 2570 new titles were screened and 152 duplicates were identified. Of the 2418 titles screened, 2347 were not relevant to the review. We read the remaining 71 articles to obtain further information and only two studies (Stevens 2006; Tie 2009) were suitable for inclusion, giving a total of seven studies in this update. See the study flow diagrams Figure 1 and Figure 2. 
Figure 1. Study flow diagram for records found during 2012 update searches

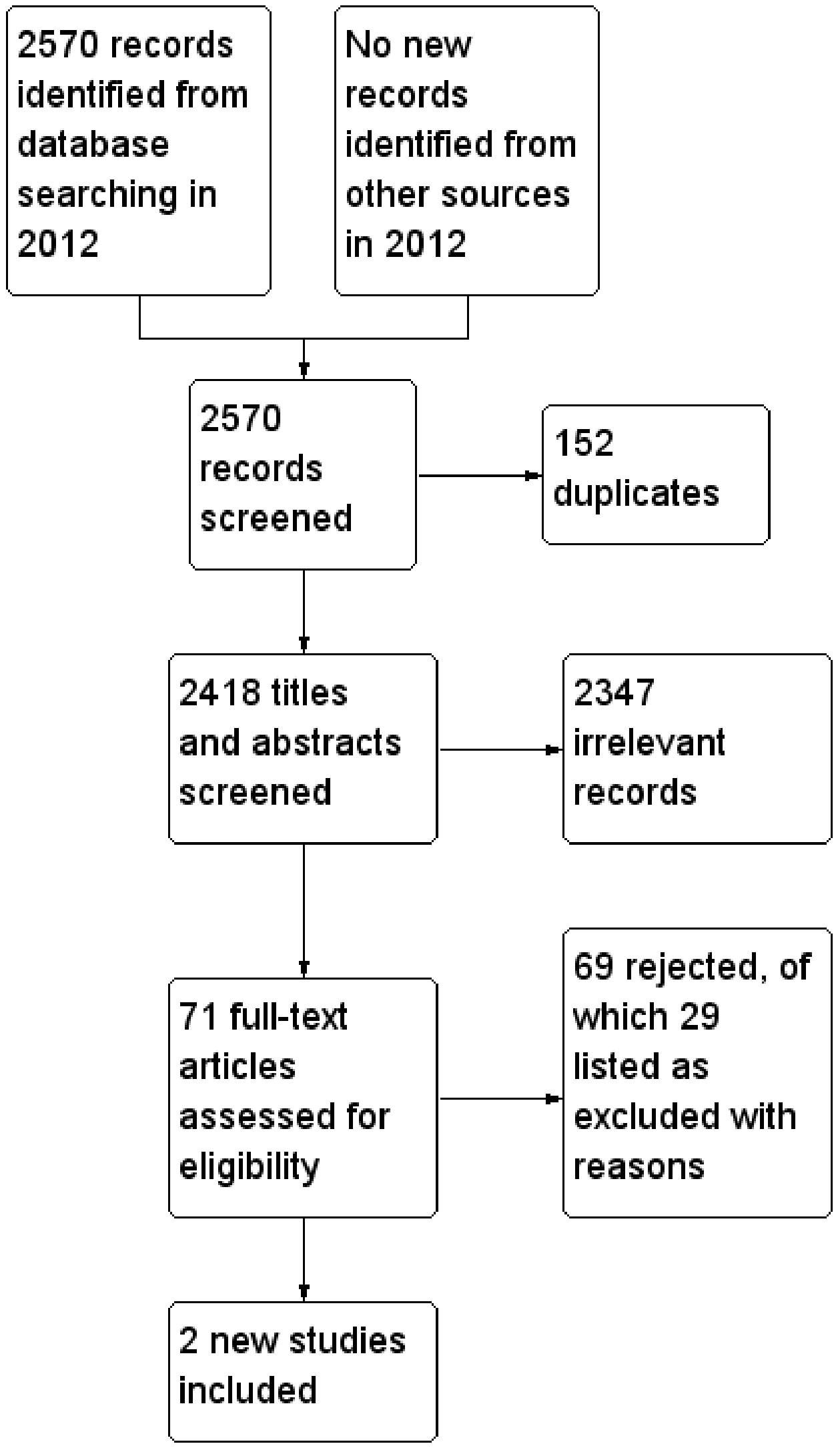


Figure 2. Study flow diagram incorporating all records for lifetime of review

1 record
identified
through other
sources in
2005

1655 records
identified
through
database
searches in 2005

2570 records identified through database searches in 2012

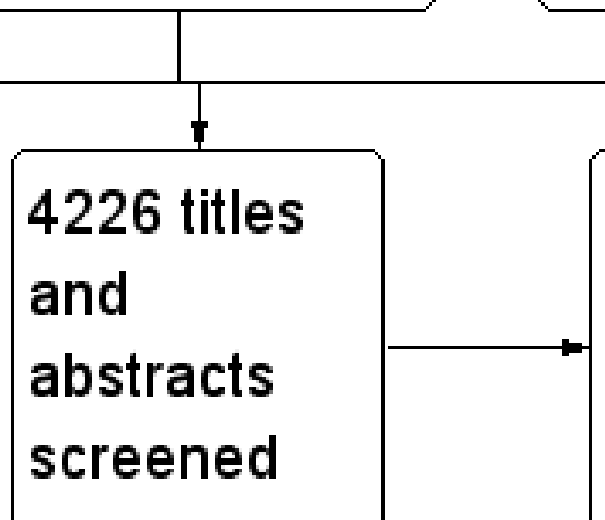

4077

duplicates

or irrelevant articles

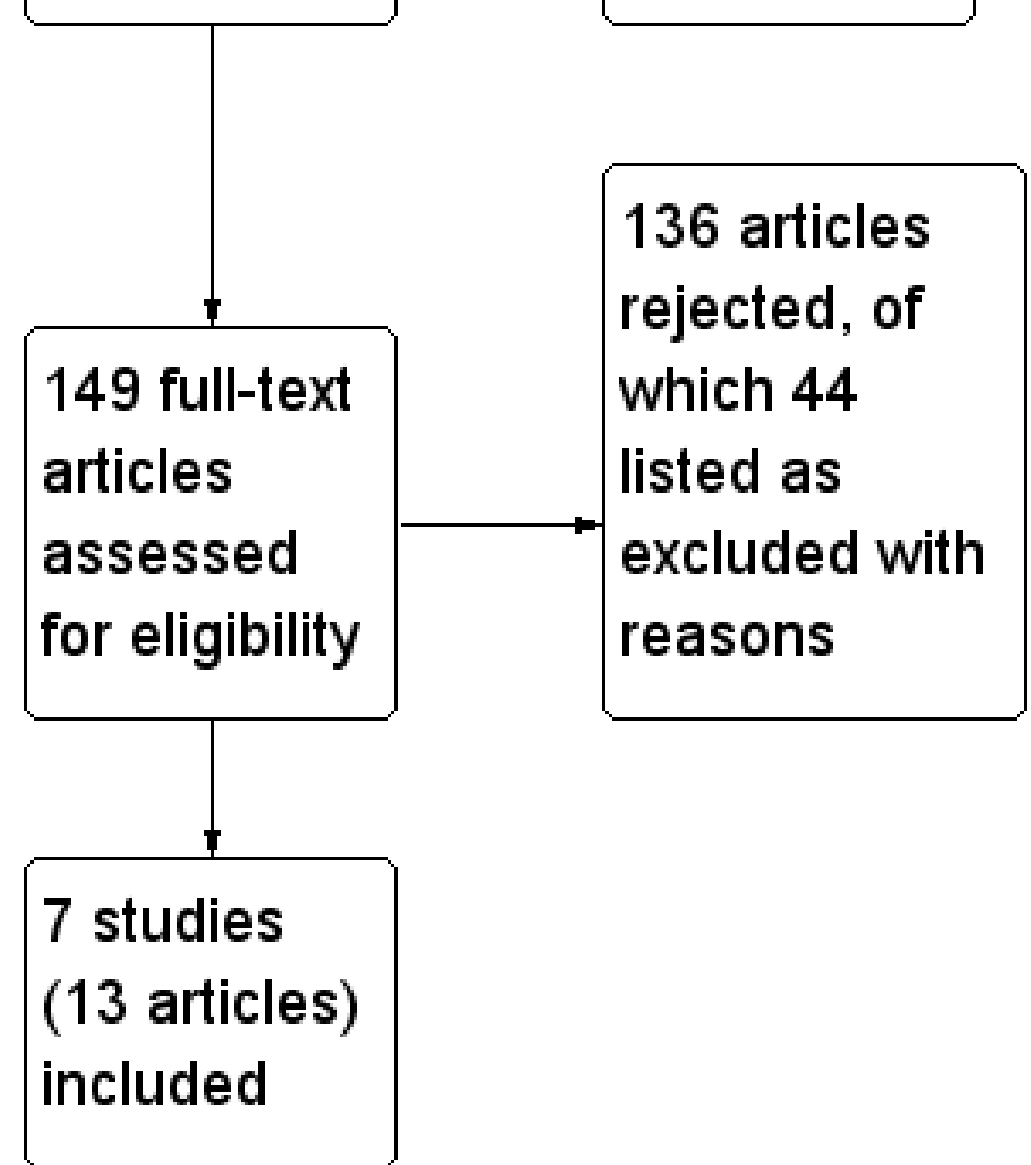




\section{Included studies}

Please see Characteristics of included studies table for more detailed information.

The number of participants in the seven included studies ranged from 29 (Stevens 2006) to 399 (Sartain 2001). The total number of participants across all the included studies was 840 . Participants in these studies ranged from three months of age through to 17 years of age. Specialist home-based nursing outreach services were provided as an intervention in each study. However, studies differed in respect of the qualifications of the nurses and their availability, including hours of service and number of visits. This is detailed in Table 1, 'Characteristics of Interventions'. No two studies examined the same intervention. In addition, treatments and outcomes varied considerably. Included studies broadly fell under the following categories.

\section{Study design}

Five trials used parallel study designs while two had a crossover study design. Participants were allocated to the intervention versus usual posthospitalisation care in two studies (Burke 1997; Stein 1984) and to traditional inpatient care in the other three (Dougherty 1998; Sartain 2001; Tie 2009). Strawczynski 1973 was a cross-over study with participants spending a year in each of the intervention and control (hospital care) groups. Another cross-over study was Stevens 2006, with participants receiving each of hospital (standard care) or home (intervention) chemotherapy alternately over a period of six months in succession.

\section{Interventions for children with acute paediatric illnesses}

There were only two studies that evaluated home-based nursing intervention for children with acute illnesses. Sartain 2001 focused on children with acute paediatric illness with breathing difficulty, diarrhoea and vomiting or fever. The intervention, home care, was defined as clinical nursing care in a patient's own home, as an alternative to hospital admission. Treatment in this study was between one and four home visits per day, with the number of days and visits determined by health professionals in conjunction with parents. This study examined readmission rates and length of stay data as outcomes. The second study (Tie 2009) compared home oxygen therapy with traditional inpatient hospital care for children with acute bronchiolitis. The children in the home care group continued with oxygen therapy at home following initial hospitalisation and were supported by the nurse home visiting programme accompanied by parental education. The outcomes assessed were readmission to hospital within seven days of discharge home and the total duration of hospitalisation.

\section{Interventions for children with a range of chronic conditions}

Stein 1984 examined home care provided to children with chronic conditions through traditional clinics, inpatient units or a home care office. The minimum package was an initial assessment, one home visit and one monthly contact thereafter for at least six months. Involvement in home care was reassessed every six months by the treating staff. This study measured outcomes related to psychological adjustment and functional status.

Another study (Burke 1997) examined a community-based stresspoint intervention provided by nursing staff to children with chronic illness. The intervention began two weeks before a planned hospital admission and continued until two weeks postdischarge. This study collected data throughout the intervention period using various scales to assess outcomes including stress and behavioural responses.

\section{Interventions for children with newly diagnosed insulin- dependent diabetes mellitus (IDDM)}

Dougherty 1998 examined home-based care provided by nursing staff over an extended period to newly diagnosed diabetic children, as an alternative to inpatient care. Nursing staff initially provided twice-daily home visits in the first few days after diagnosis, with transition to diminishing visits or phone calls to the family over two weeks, but remained available to the family for telephone contact for the next 24 months. This study focused on outcomes of diabetic management including metabolic control and diabetesrelated adverse events.

\section{Interventions for children with chronic haematological illnesses}

Strawczynski 1973 defined home care as the availability of access to a 24-hour nursing service to treat acute bleeds at home or at school for children with haemophilia, as soon as possible after they occurred. It did not report on the number of days or visits for individual children. This study reported the number of bleeds and reduction in procrastination time for haemophilia as its outcomes.

Another study (Stevens 2006) compared a hospital-based and a home-based programme for children with acute lymphoblastic leukaemia (ALL). Some of the chemotherapy treatment was delivered by the hospital pharmacy to children's homes and was then administered by a trained nurse from a community health service agency. The option of contacting a hospital oncology nurse was available to parents as required. The study outcomes were child's quality of life, the burden on parental caregivers, adverse effects and costs.

\section{Excluded studies}

Please see Characteristics of excluded studies table for details of the 41 excluded studies.

\section{Risk of bias in included studies}

The risk of bias for seven included studies was assessed using the Cochrane domain-based evaluation tool (Cochrane Handbook: Chapter 8) and is summarised below in Figure 3 and Figure 4. 
Figure 3. Risk of bias summary: review authors' judgements about each risk of bias item for each included study

\begin{tabular}{|c|c|c|c|c|c|c|c|c|}
\hline & 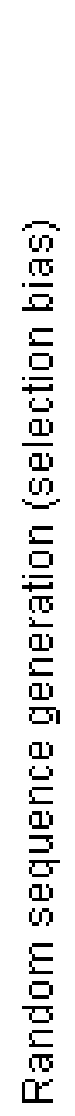 & 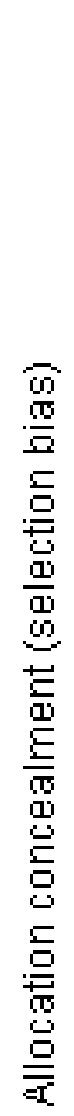 & 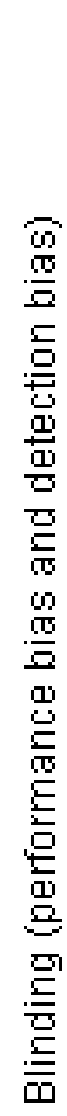 & 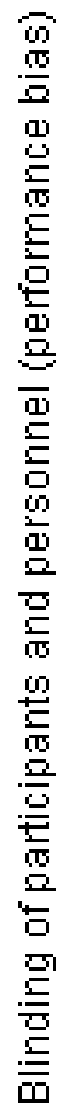 & 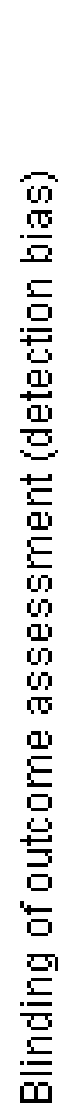 & 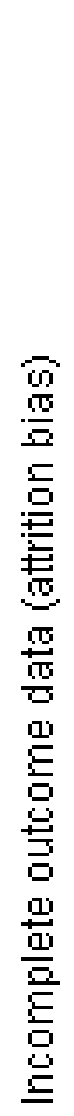 & 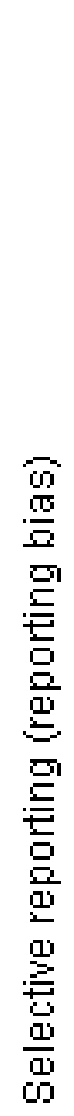 & 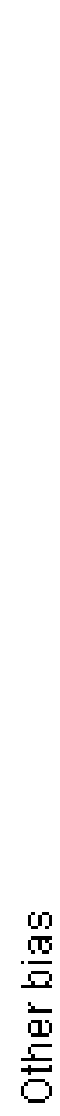 \\
\hline Burke 1997 & $?$ & & & & & & & \\
\hline Dougherty 1998 & $?$ & $?$ & & & + & & & \\
\hline Sartain 2001 & & & & & $?$ & & & \\
\hline Stein 1984 & & & & & & & & \\
\hline Stevens 2006 & + & $?$ & & & $?$ & & & \\
\hline Strawczynski 1973 & & & & & $?$ & & & \\
\hline Tie 2009 & $?$ & + & & & $?$ & & & \\
\hline
\end{tabular}


Figure 4. Risk of bias graph: review authors' judgements about each risk of bias item presented as percentages across all included studies

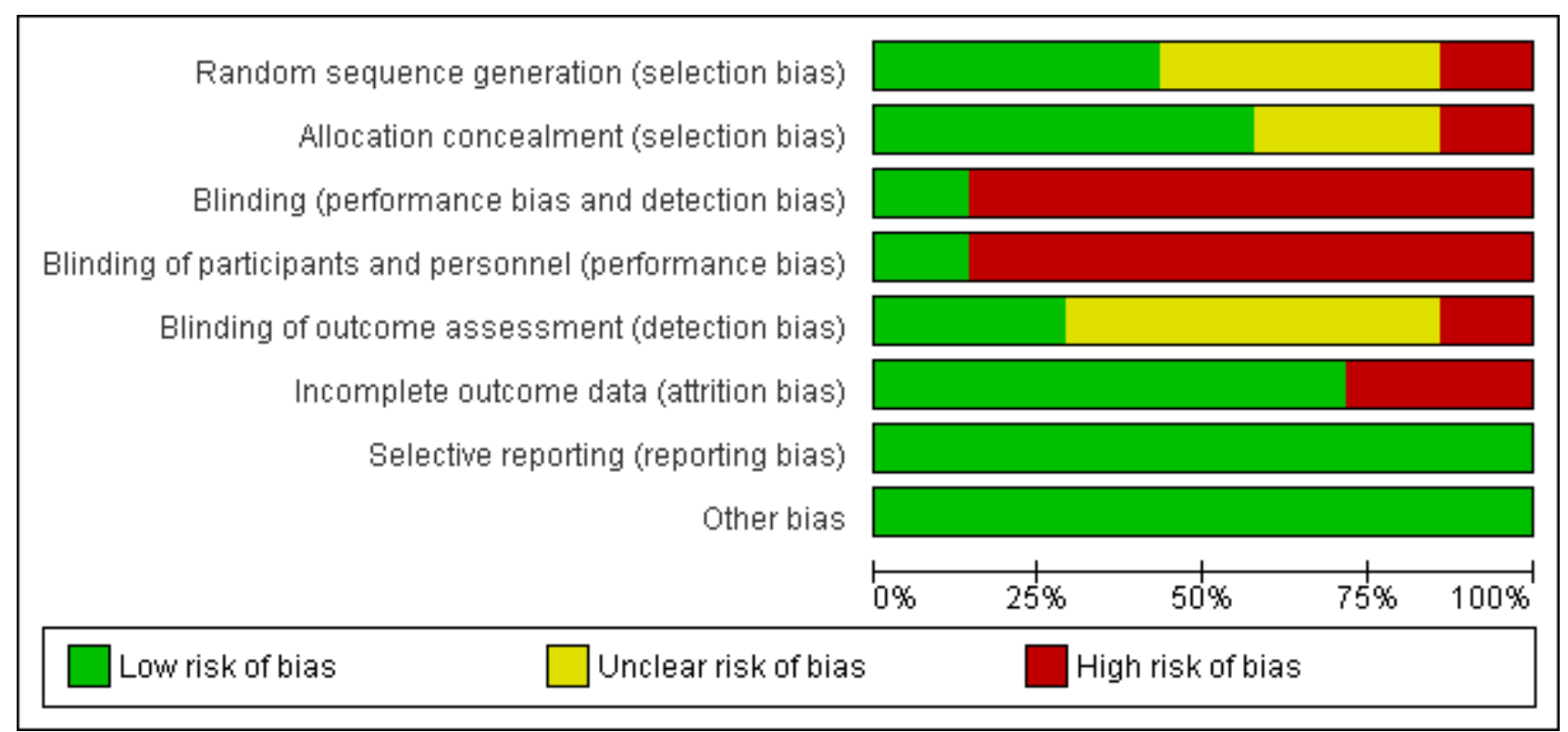

\section{Allocation}

While all seven studies stated that participants were randomised, only three gave information about the methods of randomisation or allocation concealment, and details were not reported for two studies (Dougherty 1998; Tie 2009). Opaque sealed numbered envelopes were used in one study (Sartain 2001) and a dice roll with opaque sealed envelopes in another (Stein 1984). A table of random numbers was used in a third study (Stevens 2006), but with no mention of the allocation concealment. Another study (Burke 1997) used randomisation by a secretary blinded to the study details but the method of allocation concealment was not clarified. Quasirandomisation was used in one study with alternate allocation (Strawczynski 1973).

Where necessary, we contacted study authors for clarification or missing information, but received no replies.

\section{Blinding}

Outcome assessors were reported to be blind to the intervention groups in two of the included studies. Burke 1997 used study nurses to administer the pretest to participants. Research assistants blinded to study group membership administered post-test questionnaires. Study nurses did not have contact with hospital staff during the study. In Dougherty 1998, the principal investigators were not blinded to the intervention; however, results for the intervention and control groups were not disclosed before the end of the trial. Stein 1984 made no attempt to blind interviewers to the intervention status, but there was no direct contact between the clinicians and interviewers. Strawczynski 1973 was not able to blind clinical staff to intervention status or outcome measures. Sartain 2001 had the same researcher conduct all interviews in the participant's home within two weeks of discharge. It was not stated that the interviewer was blind to group allocation; however, the allocation is likely to have been disclosed during the interview. Stevens 2006 and Tie 2009 did not mention details of blinding, but the study methodology implies that blinding of neither participants nor clinicians was possible.

\section{Incomplete outcome data}

The number of participants lost to follow-up varied. Three studies (Dougherty 1998; Sartain 2001; Tie 2009) reported no withdrawal of participants. Burke 1997 recruited 50 children and two were lost to extended follow-up (4\% loss). Loss to follow-up was $15 \%$ for Stein 1984 at six months and $17 \%$ at one year. Strawczynski 1973 enrolled 40 patients with four (10\%) lost to follow-up. Of these, one died of an intracranial haemorrhage; one developed a circulating anticoagulant, and two moved away from the study city. Stevens 2006 randomised 29 children and two from each group withdrew at the start of the study due to relapse. Throughout the study, at four data collection stages, data were not available for analysis on one or two participants from each group. Only one study (Sartain 2001) conducted an intention-to-treat analysis.

\section{Selective reporting}

All studies appear to have reported on all measured outcomes.

\section{Other potential sources of bias}

There were no other potential sources of bias in the included studies.

\section{Effects of interventions}

Meta-analysis was not appropriate in this review because of the range of outcome measures being reported. In addition, interventions were diverse and complex involving multidisciplinary teams, different hours of service and variable inclusion of educational components (see Table 1). Participants were also diverse: some had chronic illnesses such as diabetes, haemophilia, acute lymphoblastic leukaemia (ALL), and others had an acute presentation. Results are therefore presented as a written summary of individual studies only, without data synthesis. 


\section{Physical health of participants (including harmful effects)}

Stein 1984 reported presentations for concurrent illness during the period of the study and found no significant difference in general health between the intervention and control groups of children with a range of chronic conditions.

Burke 1997 identified improved parental ability to cope with illness in a chronically ill child three months postintervention $(P<0.001)$.

Dougherty 1998 reported on metabolic control and diabetesrelated adverse events in children with newly diagnosed insulindependent diabetes mellitus (IDDM). At 24 months, the home care group had lower mean $\mathrm{HbA1c}$ levels (biological measure of diabetic control), $6.1 \%$ versus $6.8 \%(P<0.02)$. There was no difference between the two groups for adverse diabetes-related clinical events.

Strawczynski 1973 reported on the number of bleeds and procrastination time in children with haemophilia presenting with a bleed. Overall, significantly more bleeding episodes were reported in the home care programme, with the majority of these being mild to moderate bleeds. Severe bleeds were significantly more likely in the hospital programme ( $P$ value not reported). Procrastination time was defined as the time elapsed between the bleed occurring and reporting for treatment. Reported procrastination time decreased in the intervention group (mean 17 hours, compared to 29 hours in the control group; $P$ value and significance not reported).

Stevens 2006 used Pediatric Oncology Quality of Life Scale (POQOLS) to assess quality of life, and reported no significant longterm difference between the hospital and home treatment groups in values for sensitivity to restrictions in physical functioning and the ability to maintain a normal physical routine.

\section{Mental health of participants}

Stein 1984 reported on psychological adjustment for children with a range of chronic conditions. For children five years and older, there was a significant improvement in the child's psychological adjustment at six months postintervention $(P<0.05)$, with some diminution by 12 months postintervention $(P<0.10)$. Mothers in the home care group showed improvement in mental health symptoms compared to those in the control group $(P=0.07)$.

Burke 1997 reported on the behaviour and anxiety of children with a range of chronic conditions. There was no significant difference between the two groups for child behaviour. However, at three months postintervention, intervention group parents were less anxious, with this difference being statistically significant. The intervention group had significantly less discrepancy between desired and actual family functioning at the end of three months of intervention.

Stevens 2006 used Child Behavior Checklist scores to identify behavioural problems and social competence among the study participants and reported no significant difference between intervention and control groups at any of the follow-up periods.

\section{The utilisation of emergency departments (EDs)}

No studies offered data for this outcome.

\section{Hospital admissions}

Sartain 2001 reported that there were no significant differences between home care and hospital care readmissions over 90 days, at $21(10.0 \%)$ and $15(7.9 \%)$ respectively $(P=0.49)$. Of those in home care, 14 were readmitted once $(7 \%)$, two were readmitted twice $(1 \%)$ and one child was readmitted three times (1\%). For hospital care, $13(7 \%)$ were readmitted once and one $(<1 \%)$ twice. No child was readmitted more than twice. No other studies reported on this outcome.

Tie 2009 reported that hospital readmission rates were the same for children with acute bronchiolitis within seven days of discharge for traditional hospital care versus home care. One child from each group of 22 participants required readmission.

\section{Length of stay in hospital}

Four studies reported on length of service provision. This was reported in several ways, including bed days, inpatient stay and use of hospital-based services. Sartain 2001 reported that children with acute illnesses who were in the control group, i.e. usual hospital treatment, were more likely to have a longer stay than those in the home care group, with mean bed stay of 2.37 versus 1.37 days $(P<$ 0.0001).

Dougherty 1998 reported that there was no difference between both groups in the mean days spent in the intensive care unit at diagnosis. However, mean hospital inpatient stay was lower with home-based care $(2.2+/-1.6$ nights, 70 total) compared to hospital-based care $(4.7+/-1.6$ nights, 147 total). The use of services while hospitalised was lower for the home-based group, logistically because of shorter initial hospital stay. However, they did report that children receiving home care used more diabetes nursing hours during the 24-month period, 58.9 hours per child compared with 17.3 hours for standard care ( $P$ value and significance not stated), which implies that the intervention required more intensive nursing support.

Strawczynski 1973 reported the total number of treatment days for children with haemophilia in the home care group was 2030 compared with 1644 for the hospital-based group. However, only 241 from the home care group needed hospitalisation during the treatment period ( $P$ value and significance not reported).

Tie 2009 reported that children in the 'hospital in the home' treatment group spent significantly less time in a hospital bed (55.2 hours) than those in the hospital group (96.9 hours) $(P=0.001)$.

\section{Parental, child and referrer satisfaction}

Sartain 2001 collected parent-reported data for children with acute paediatric illnesses from a subset of the intervention group, which found that 36 of $40(90 \%)$ parents and 7 of $11(66 \%)$ children would prefer to access a 'Hospital at Home' service. There was a perception that children receiving the 'Hospital at Home' service recovered more quickly in their own environment and that there was less social disruption and financial burden for the family.

Stein 1984 identified overall greater satisfaction from respondents, with medical care provided in the home care group $(P<0.05)$ for children with a range of chronic conditions. 


\section{Quality of life of children and their carers}

At three months post-intervention, Burke 1997 reported that for children with chronic illnesses, the home care group had greater satisfaction in family functioning $(P<0.001)$; greater parental ability to cope $(P<0.001)$; greater family ability to cope $(P<0.001)$; a greater ability in personal and social care coping $(P<0.01)$; and a greater perception of helpfulness from healthcare providers and institutional sources $(P<0.001)$.

Stein 1984 did not observe a significant difference for the impact of chronic illness on families between those receiving home care and those in the control group $(P=0.14)$.

Strawczynski 1973 reported significantly better school attendance ( $P$ value not stated) in the home care group, with an average of 2.5 school days missed compared to six days in the hospital programme for children with haemophilia.

Stevens 2006 reported no evidence of an effect of the location (i.e. home or hospital) where chemotherapy was administered in relation to parental burden of care using Caregiving Burden Scale (CBS) at different stages during the study period. Another important finding was that the age of the child was a significant predictor, with inverse effect being observed on quality of life, caregiver burden and adverse events.

\section{Costs}

Sartain 2001 assessed costs for children with acute paediatric illnesses in a separate paper (Bagust 2002). A number of parents thought that hospital care was more costly for them, with $20 \%$ of parents in the home care programme commenting on savings resulting from remaining at home and $30 \%$ of parents in the hospital care group commenting on the financial cost of the child staying in hospital.

Dougherty 1998 found that for children with newly diagnosed IDDM, there were social cost savings. This means that there were savings across hospital, physicians, tax payers and families. There were also parental cost savings (difference between out-of-pocket expenses and the value of their time diverted to care for their child from other activities) of CAD 188 for each child on the home care programme $(P<0.001)$ and an increased cost to the hospital of CAD 87 per child on the home care programme $(P<0.001)$.

Strawczynski 1973 reported total costs for providing both the home care and the hospital programme but did not give separate information on costs for the intervention and control groups.

Stevens 2006 did not find any significant difference between costs for the family (societal perspective) associated with home chemotherapy and standard care $(P=0.79)$.

\section{DISCUSSION}

\section{Summary of main results}

Two studies of children with acute paediatric illnesses (Sartain 2001; Tie 2009) reported a statistically significant reduction in the duration of hospital stay, with no significant difference in readmission rates

A variety of assessment tools were used in the studies included in this review to measure the functional impact or quality of life.
Burke 1997 found that home-care parents postintervention had better coping skills, family functioning and a reduction in anxiety than those in the traditional care group. No differences in child behaviour were reported in either group. A similar finding of no significant differences in child behaviour was reported in two other studies (Dougherty 1998; Stevens 2006) which used Child Behaviour Checklist $(\mathrm{CBCL})$ for the assessment. A reduction in parental anxiety was noted in two other studies, with Burke 1997 and Stein 1984 reporting an improvement in mental health symptoms for mothers in the study group. Another study (Strawczynski 1973) reported better school attendance in the home-care children. Stein 1984 did not detect any significant impact of the intervention on the functional status of the participating children; Stevens 2006 reported that neither home or hospital location for treatment affected the parental burden of care. Overall, parental satisfaction with the home-based nursing care was reported in three studies (Sartain 2001; Stein 1984; Strawczynski 1973) which included semistructured parental interviews.

Cost effectiveness was not comprehensively addressed by any of the included studies. Three studies presented limited cost data. Dougherty 1998 suggested that the financial cost to the hospital of providing the home-based care programme may cost more than the hospital-based care, but suggested that there are substantial cost savings for the family from the home-care programme. This view was supported by Sartain 2001, who presented qualitative data on cost savings for families in the home-care programme versus increased expenditure for families in the hospital-care group. Interestingly, Stevens 2006 did not find any difference in family costs from a societal perspective in either home- or hospital-based treatment groups.

\section{Overall completeness and applicability of evidence}

There was wide clinical diversity between studies due to differences in participants, disease or condition requiring care, interventions and outcomes measured. There was also variation in the statistical methods used by studies. For these reasons, we did not conduct meta-analyses, which should be taken into consideration when drawing conclusions from this review. Few benefits of homebased nursing care were evident in the included studies. However, current studies (Dougherty 1998; Sartain 2001; Stevens 2006) do not take into account the original set-up costs of traditional inpatient services, or the long-term cost savings for children and families achieved by a less disruptive model of care. Further research is required that examines the long-term costs to both service providers and families before an economic rationalisation of home care can be attempted.

\section{Quality of the evidence}

This systematic review included seven randomised controlled trials with 840 participants ranging from three months to 17 years. Only one study (Burke 1997) blinded participants and personnel while only two blinded the process of outcome assessment (Burke 1997; Dougherty 1998). The risks of performance and detection bias should be considered when interpreting results of the relevant studies. Also, some studies have a limited sample size which impacts on the statistical power of the study. 


\section{Potential biases in the review process}

The authors followed the process of systematic review as detailed in the Cochrane Handbook and have tried to minimise the likelihood of potential biases in the review process.

\section{Agreements and disagreements with other studies or reviews}

The findings of reduction of hospital stay and hospital readmission rates with home-based nursing care are consistent with some findings from the previously published literature (Meates 1997; Smith 1986; Whiting 1997). A recent systematic review (Parker 2012) on the paediatric home care services reported some evidence of reduced burden and costs for families, particularly in relation to acute admission avoidance. This is consistent with some of the cost-effectiveness findings in the studies included in this review. A mixed-methods study based in the UK (Spiers 2012 ) enumerates the diversity and complexity as well as variable clinical coverage of the service delivery models which are categorised as 'care closer to home'. This is consistent with the diverse clinical settings of the included studies in this review.

\section{AUTHORS' CONCLUSIONS}

\section{Implications for practice}

This systematic review has demonstrated a limited evidence base for home care programmes, with few randomised controlled trials undertaken, clinical and methodological heterogeneity between trials that have been completed. At present, there is insufficient evidence to support the effectiveness of specialist paediatric nurse home visiting for acute and chronic illnesses in reducing hospital admissions and Emergency Department utilisation. However, there is suggestive evidence that home care programmes may lead to greater parent satisfaction, improved quality of life and a reduction in the length of hospital stay. The cost effectiveness of these programmes is still to be determined.

\section{Implications for research}

Additional randomised controlled trials are required to examine home care programmes for children with acute and chronic illnesses across the full age range of birth to 18 years. Adequate sample sizes must be used to generate the statistical power to detect differences between the intervention and control groups. Clinically relevant outcomes need to be defined for utilisation of Emergency Departments and length of hospital stay; physical health determinants; mental health determinants; and satisfaction measures. It would be useful if there were a standardised and consistent method of measuring these clinically relevant outcomes across studies, in particular, a definition of readmission to hospital and a standardised questionnaire for measuring parental satisfaction. While data for disease-specific diagnostic groupings would be the ideal, in reality ambulatory care programmes are usually set up in local populations to address a range of acute and chronic conditions. These include, but are not limited to, ambulatory sensitive conditions such as asthma and gastroenteritis.

Currently there are no data to support comprehensive costings for home care programmes from the perspective of a health organisation and the family. Complete evaluation of home care programmes requires estimation of both direct costs to healthcare providers and indirect costs to the child and their family, as well as to society. While healthcare provider costs may be readily assessable, the indirect costs of time off work, loss of earnings and childcare expenses must also be considered. The recently published systematic review (Parker 2012) on this topic refers to the need for additional high-quality research and collection of goodquality service level data with details about effects on the health economy. It also mentions that the evidence for paediatric homebased services continues to grow slowly.

\section{ACKNOWLEDGEMENTS}

The authors wish to thank Jo Abbott and Jane Dennis of the Cochrane Developmental, Psychosocial and Learning Problems Group for their assistance with literature searching and review development, as well as Michelle Irving, Celia Almeida and Eva Lloyd of the University of Bristol, UK, for translating journal articles.

The authors wish to thank Laura MacDonald, Managing Editor, Cochrane Developmental, Psychosocial and Learning Problems Group, for her support during development of the update of this review. 


\section{R E F E R E N C E S}

\section{References to studies included in this review}

\section{Burke 1997 \{published data only\}}

Burke SO, Handley-Derry MH, Costello EA, Kauffmann E, Dillon MC. Stress-point intervention for parents of repeatedly hospitalized children with chronic conditions. Research in Nursing and Health 1997;20(6):475-85.

\section{Dougherty 1998 \{published data only\}}

Dougherty G, Schiffrin A, White D, Soderstrom L, Sufrategui M. Home-based management can achieve intensification costeffectively in type 1 diabetes. Pediatrics 1999;103(1):122-8.

* Dougherty GE, Soderstrom L, Schiffrin A. An economic evaluation of home care for children with newly diagnosed diabetes: results from a randomized controlled trial. Medical Care 1998;36(4):586-98.

\section{Sartain 2001 \{published data only\}}

Bagust A, Haycox A, Sartain SA, Maxwell MJ, Todd P. Economic evaluation of an acute paediatric hospital at home clinical trial. Archives of Disease in Childhood 2002;87(6):489-92.

Sartain SA, Maxwell MJ, Todd PJ, Haycox AR, Bundred PE. Users' views on hospital and home care for acute illness in childhood. Health and Social Care in the Community 2001;9(2):108-17.

* Sartain SA, Maxwell MJ, Todd PJ, Jones KH, Bagust A, Haycox A, et al. Randomised controlled trial comparing an acute paediatric hospital at home scheme with conventional hospital care. Archives of Disease in Childhood 2002;87(5):371-5.

\section{Stein 1984 \{published data only\}}

Jessop DJ, Stein RE. Providing comprehensive health care to children with chronic illness. Pediatrics 1994;93(4):602-7.

Jessop DJ, Stein RE. Who benefits from a pediatric home care program?. Pediatrics 1991;88(3):497-505.

Stein RE, Jessop D. Long-term mental health effects of a pediatric home care program. Pediatrics 1991;88(3):490-6.

* Stein RE, Jessop DJ. Does pediatric home care make a difference for children with chronic illness? Findings from the Pediatric Ambulatory Care Treatment Study. Pediatrics 1984;73(6):845-53

\section{Stevens 2006 \{published data only\}}

Stevens B, Croxford R, McKeever P, Yamanda J, Booth M, Dacub S, et al. Hospital and home chemotherapy for children with leukemia: a randomized cross-over study. Pediatric Blood and Cancer 2006;47(3):285-92.

\section{Strawczynski 1973 \{published data only\}}

Strawczynski H, Stachewitsch A, Morgenstern G, Shaw M. Delivery of care to hemophiliac children: home care versus hospitalization. Pediatrics 1973;51(6):986-91.
Tie 2009 \{published data only\}

Tie SW, Hall GL, Peter S, Vine J, Verheggen M, Pascoe EM, et al. Home oxygen for children with acute bronchiolitis. Archives of Disease in Childhood 2009;94(8):641-3.

\section{References to studies excluded from this review}

Affleck 1989 \{published data only\}

Affleck G, Tennen H, Rowe J, Roscher B, Walker L. Effects of formal support on mother's adaptation to the hospital to home transition of high risk infants: the benefits and costs of helping. Child Development 1989;60(2):488-501.

Alexander 1988 \{published data only\}

Alexander JS, Younger RE, Cohen RM, Crawford LV. Effectiveness of a nurse-managed program for children with chronic asthma. Journal of Pediatric Nursing 1988;3(5):312-7.

\section{Badr 2006 \{published data only\}}

Badr LK, Garg M, Kamath M. Intervention for infants with brain injury: results of a randomized controlled study. Infant Behavior and Development 2006;29(1):80-90.

Bang 1999 \{published data only\}

Bang AT, Bang RA, Baitule SB, Reddy MH, Deshmukh MD. Effect of home-based neonatal care and management of sepsis on neonatal mortality: field trial in rural India. Lancet 1999;354(9194):1955-61.

\section{Beckwith 1988 \{published data only\}}

Beckwith L. Intervention with disadvantaged parents of sick preterm infants. Psychiatry 1988;51(3):242-7.

Black 1995 \{published data only\}

* Black MM, Dubowitz H, Hutcheson J, Berenson-Howard J, Starr RH Jr. A randomized clinical trial of home intervention for children with failure to thrive. Pediatrics 1995;95(6):807-14.

Hutcheson JJ, Black MM, Talley M, Dubowitz H, Howard JB, Starr RH Jr, et al. Risk status and home intervention among children with failure-to-thrive: follow-up at age 4. Journal of Pediatric Psychology 1997;22(5):651-68.

\section{Blakeslee 1997 \{published data only\}}

Blakeslee DB, Jafek BW, Birney JL. An optimal choice: home intravenous hydration after tonsillectomy. Laryngoscope 1997;107(10):1332-5.

\section{Brooten 1986 \{published data only\}}

Brooten D, Gennaro S, Knapp H, Jovene N, Brown L, York R. Functions of the CNS in early discharge and home followup of very low birthweight infants. Clinical Nurse Specialist 1991;5(4):196-201.

* Brooten D, Kumar S, Brown L, Butts P, Finkler S, BakewellSachs $M$, et al. A randomized clinical trial of early hospital discharge and home follow-up of very low birth-weight infants. New England Journal of Medicine 1986;315(15):934-9. 
Brown 2002 \{published data only\}

Brown JV, Bakeman R, Celano MP, Demi AS, Kobrynski L, Wilson SR. Home-based asthma education of young low-income children and their families. Journal of Pediatric Psychology 2002;27(8):677-88.

Brown JV, Demi AS, Celano M, Bakeman R, Kobrynski L, Wilson SR. A home visiting asthma education program: challenges to program implementation.. Health Education and Behavior 2005;32(1):42-56.

\section{Broyles 2000 \{published data only\}}

Broyles RS, Tyson J, Heyne ET, Heyne RJ, Hickman JF, Swint M, et al. Comprehensive follow up care and life-threatening illnesses among high risk infants: a randomised controlled trial. JAMA 2000;284(16):2070-6.

\section{Butz 1994 \{published data only\}}

Butz AM, Malveaux FJ, Eggleston P, Thompson L, Schneider S, Weeks $\mathrm{K}$, et al. Use of community health workers with inner-city children who have asthma. Clinical Pediatrics 1994;33(3):135-41.

\section{Butz 2006 \{published data only\}}

Butz Am, Tsoukleris MG, Donithan M, Hsu VD, Zuckerman I, Mudd KE, et al. Effectiveness of nebulizer use-targeted asthma education on underserved children with asthma. Archives of Pediatrics and Adolescent Medicine 2006;160(6):622-8.

\section{Caliskan Yilmaz 2010 \{published data only\}}

Caliskan Yilmaz M, Ozsoy SA. Effectiveness of a dischargeplanning program and home visits for meeting the physical care needs of children with cancer. Supportive Care in Cancer 2010;18(2):243-53.

\section{Casiro 1993 \{published data only\}}

Casiro OG, McKenzie ME, McFadyen L, Shapiro C, Seshia MMK, MacDonald N, et al. Earlier discharge with community-based intervention for low birth weight infants: a randomized trial. Pediatrics 1993;92(1):128-34.

Catov 2005 \{published data only\} Catov JM, Marsh GM, Youk AO, Huffman VY. Asthma home teaching: two evaluation approaches. Disease Management 2005;8(3):178-87.

\section{Crowin 2005 \{published data only\}}

Crowin P, Toop L. Randomised controlled trial of intravenous treatment for cellulitis at home compared with hospital. BMJ 2005;330(7483):129.

\section{Deaves 1993 \{published data only\}}

Deaves DM. An assessment of the value of health education in the prevention of childhood asthma. Journal of Advanced Nursing 1993;18(3):354-63.

\section{Dolinar 2000 \{published data only\}}

Dolinar R-M, Kumar V, Coutu-Wakulczyk G, Rowe B. Pilot study of a home-based asthma health education program. Patient Education and Counseling 2000;40(1):93-102.

\section{Donati 1987 \{published data only\}}

Donati MA, Guenette G, Auerbach H. Prospective controlled study of home and hospital therapy of cystic fibrosis pulmonary disease. Journal of Pediatrics 1987;111(1):28-33.

\section{Greineder 1999 \{published data only\}}

Greineder DK, Loane KC, Parks P. A randomized controlled trial of a pediatric asthma outreach program. Journal of Allergy and Clinical Immunology 1999;103(3):436-40.

\section{Hatziagorou 2010 \{published data only\}}

Hatziagorou E, Kirvassilis F, Avramidou V, Ioannou M, Tsanakas J. Home intravenous antibiotic treatment of children with cystic fibrosis: clinical, quality of life and cost aspects. 33rd European Cystic Fibrosis Conference Valencia Spain, 16-19 June 2010.

\section{Heikens 1994 \{published data only\}}

Heikens GT, Schofield WN, Dawson SM, Waterlow JC. Long-stay versus short-stay hospital treatment of children suffering from severe protein-energy malnutrition. European Journal of Clinical Nutrition 1994;48(12):873-82.

Hughes 1991 \{published data only\}

Hughes DM, McLeod M, Garner B, Goldbloom RB. Controlled trial of a home and ambulatory program for asthmatic children. Pediatrics 1991;87(1):54-61.

Keefe 2006 \{published data only\}

Keefe MR, Lobo ML, Froese-Fretz A, Kotzer AM, Barbosa GA Dudley WN. Effectiveness of an intervention for colic. Clinical Pediatrics 2006;45(2):123-33.

\section{Krieger 2009 \{published data only\}}

Krieger J, Takaro TK, Song L, Beaudet N, Edwards K. A randomized controlled trial of asthma self-management support comparing clinic-based nurses and in-home community health workers: the Seattle-King County Healthy Homes II Project. Archives of Pediatrics and Adolescent Medicine 2009;163(2):141-9.

\section{Lindberg 2002 \{published data only\}}

Lindberg M, Ahlner J, Ekstrom T, Jonsson D, Moller M. Asthma nurse practice improves outcomes and reduces costs in primary health care. Scandinavian Journal of Caring Sciences 2002;16(1):73-8.

\section{Madge 1997 \{published data only\}}

Madge P, McColl J, Paton J. Impact of a nurse-led home management training programme in children admitted to hospital with acute asthma: a randomised controlled study. Thorax 1997;52(3):223-8.

\section{McConnochie 1999 \{published data only\}}

McConnochie KM, Russo MJ, McBride JT, Szilagyi PG, Brooks AM, Roghmann KJ. How commonly are children hospitalized for asthma eligible for care in alternative settings?. Archives of Pediatrics and Adolescent Medicine 1999;153(1):49-55. 
Mitchell 1986 \{published data only\}

Mitchell EA, Ferguson V, Norwood M. Asthma education by community child health nurses. Archives of Disease in Childhood 1986;61(12):1184-9.

\section{Park 2002 \{published data only\}}

Park AH, Kim H. Intravenous home hydration in pediatric patients following adenotonsillectomy. International Journal of Pediatric Otorhinolaryngology 2002;66(1):17-21.

\section{Raynor 1999 \{published data only\}}

Raynor P, Rudolf MCJ, Cooper K, Marchant P, Cottrell D. A randomised controlled trial of specialist health visitor intervention for failure to thrive. Archives of Disease in Childhood 1999;80(6):500-6.

\section{Rieger 1995 \{published data only\}}

Rieger ID, Henderson-Smart DJ. A neonatal early discharge and home support programme: shifting care into the community. Journal of Paediatrics and Child Health 1995;31(1):33-7.

\section{Schuttelaar 2010 \{published data only\}}

Schuttelaar MLA, Vermeulen KM, Drukker M, Coenraads PJ. A randomized controlled trial in children with eczema: nurse practitioner vs. dermatologist. British Journal of Dermatology 2010;162(1):162-70.

\section{Shin 2009 \{published data only\}}

Shin JY, Nhan NV, Lee SB, Crittenden KS, Flory M, Hong HTD. The effects of a home-based intervention for young children with intellectual disabilities in Vietnam. Journal of Intellectual Disability Research 2009;53(4):339-52.

\section{Svahn 2002 \{published data only\}}

Svahn BM, Remberger M, Myrback KE, Holmberg K, Eriksson B, Hentschke $P$, et al. Home care during the pancytopenic phase after allogeneic hematopoietic stem cell transplantation is advantageous compared with hospital care. Blood 2002;100(13):4317-24

\section{Svahn 2008 \{published data only\}}

Svahn B-M, Remberger M, Heijbel M, Martell E, Wikstrom M, Eriksson B, et al. Case-control comparison of at-home and hospital care for allogeneic hematopoietic stem-cell transplantation: the role of oral nutrition. Transplantation 2008;85(7):1000-7.

\section{Talabere 1993 \{published data only\}}

Talabere LR. The effects of an asthma education program on selected health behaviors of school-aged children with asthma. In: Funk SG, et al. editor(s). Key Aspects of Caring for the Chronically Ill: Hospital and Home. New York: Springer Publishing Co, 1993:319-30.

\section{Tiberg 2011 \{published data only\}}

Tiberg I, Steen Carlsson K. A randomised controlled trial comparing hospital based and hospital based home care when a child is newly diagnosed with type 1 diabetes. Proceedings of the 37th Annual Meeting of the International Society for Pediatric and Adolescent Diabetes, (ISPAD), Miami Beach, FL, United States, 19-22 October 2011.
Wang 1995 \{published data only\}

Wang EE, Wright JG, Whiting JL. Do home visits by nurses reduce day surgery cancellation rates? Results of a randomized controlled trial. Medical Care 1995;33(1):113-8.

\section{Wolter 1997 \{published data only\}}

Wolter JM, Bowler SD, Nolan PJ, McCormack JG. Home intravenous therapy in cystic fibrosis: a prospective randomized trial examining clinical, quality of life and cost aspects. European Respiratory Journal 1997;10(4):896-900.

\section{Wright 1998 \{published data only\}}

Wright C, Callum J, Birks E, Jarvis S. Effect of community based management in failure to thrive: randomised controlled trial. BMJ 1998;317(7158):571-4.

\section{Additional references}

\section{Bagust 2002}

Bagust A, Haycox A, Sartain SA, Maxwell MJ, Todd P. Economic evaluation of an acute ppaediatric hospital at home clinical trial. Archives of Disease in Childhood 2002;9(2):108-17.

\section{Beebe 1993}

Beebe S, Casey R, Magnusson MR, Pasquariello PS. Comparison of self-referred and physician-referred patients to a pediatric diagnostic center. Clinical Pediatrics 1993;32(7):412-6.

\section{Bowling 1987}

Bowling A, Isaacs D, Armston J, Roberts JE, Elliott EJ. Patient use of a paediatric hospital casualty department in the East End of London. Family Practice 1987;4(2):85-90.

\section{Box 1993}

Box J. Family affair. Nursing Times 1993;89(39):37-8.

\section{Boyle 2000}

Boyle R, Smith C, McIntyre J. The changing utilization of a children's emergency department. Ambulatory Child Health 2000;6(1):39-43.

\section{Browne 1996}

Browne GJ, Penna A. Short stay facilities: the future of efficient paediatric emergency services. Archives of Disease in Childhood 1996;74(4):309-13.

\section{Cochrane Handbook}

Higgins JPT, Green S (editors). Cochrane Handbook for Systematic Reviews of Interventions. Version 5.1.0 [updated March 2011]. The Cochrane Collaboration, 2011. Available from www.cochrane-handbook.org.

\section{Cooper 2000}

Cooper CD. Utilisation of a District Hospital Emergency Department for Children and Adolescents. Sydney: University of Sydney, 2000. 


\section{Cooper 2003}

Cooper CD, Simpson JM, Hanson R. The district hospital emergency department: why do parents present?. Emergency Medicine 2003;15:68-76.

\section{Farquahar 1990}

Farquahar M. The use and mis-use of paediatric casualty. Nurse Standard 1990;4(26):34-5.

\section{Fradd 1994}

Fradd E. Whose responsibility?. Nurse Times 1994;90(6):34-6.

\section{Grover 1994}

Grover G, Berkowitz CD, Lewis RJ. Parental recall after a visit to the emergency department. Clinical Pediatrics 1994;33(4):194-201.

\section{Halfon 1996}

Halfon N, Newacheck PW, Wood DL, St Peter RF. Routine emergency department use for sick care by children in the United States. Pediatrics 1996;98(1):28-34.

\section{Higgins 2002}

Higgins JPT, Thompson SG. Quantifying heterogeneity in a meta-analysis. Statistics in Medicine 2002;21(11):1539-58.

\section{Jones 1999}

Jones DS, McNagny SE, Williams MV, Parker RM, Sawyer MF, Rask KJ. Lack of a regular source of care among children using a public hospital emergency department. Pediatric Emergency Care 1999;15(1):13-6.

\section{Kai 1996}

Kai J. What worries parents when their preschool children are acutely ill, and why: a qualitative study. BMJ 1996;313(7063):983-7.

\section{Kelly 1994}

Kelly JT. Evaluating quality performance in alternative health care delivery systems: a critical challenge. JAMA 1994;271(20):1620-1.

\section{Lefebvre 2008}

Lefebvre C, Manheinmer E, Glanville J. Chapter 6: Searching for studies. In: Higgins JPT, Green S editor(s). Cochrane Handbook for Systematic Reviews of Interventions. Chichester: John Wiley \& Sons, 2008

\section{Lenihan 1985}

Lenihan S. The young child and the home health care nurse: problems, challenges and intervention strategies. Home Healthcare Nurse 1985;3(6):6-9.

\section{Madigan 1997}

Madigan EA. An introduction to paediatric home healthcare. Journal of the Society of Pediatrics Nurses 1997;2(4):172-8.

\section{McConnochie 1998}

McConnochie KM, Callahan CM, Coners GP, Roghmann KJ. Estimating risk associated with care in alternative settings: deterioration among children hospitalised. Archives of Pediatrics and Adolescent Medicine 1998;152(7):651-8.

\section{Meates 1997}

Meates M. Ambulatory paediatrics-making a difference. Archives of Disease in Childhood 1997;76:468-76.

\section{Montalto 1998}

Montalto M. How safe is hospital-in-the-home care?. Medical Journal of Australia 1998;168(6):277-80.

\section{Parker 2012}

Parker G, Spiers G, Gridley K, Atkin K, Birks Y, Lowson K, et al. Systematic review of international evidence on the effectiveness and costs of paediatric home care for children and young people who are ill. Child: Care, Health and Development 2012;39(1):1-19.

\section{Smith 1986}

Smith J. The ward moves out. Nursing Times 1986;82(34):44.

\section{Spiers 2012}

Spiers G, Gridley K, Cusworth L, Mukharjee S, Heaton J, Atkin $\mathrm{K}$, et al. Understanding care closer to home for ill children and young people. Nursing Children and Young People 2012;24(5):29-34.

\section{While 2000}

While AE, Dyson L. Characteristics of paediatric home care provision: the two dominant models of care in England. Childcare Health and Development 2000;26(4):263-75.

\section{Whiting 1997}

Whiting M. Community children's nursing: a bright future?. Paediatric Nursing 1997;9(4):6-8.

\section{Worsley 1985}

Worsley LW, Hanson RM, Yu JS. Paediatric accident and emergency services - are we meeting the need?. Australian Health Review 1985;8(3):189-93.

\section{References to other published versions of this review Cooper 2006}

Cooper C, Wheeler DM, Woolfenden S, Boss T, Piper S. Specialist home-based nursing services for children with acute and chronic illnesses. Cochrane Database of Systematic Reviews 2006, Issue 4. [DOI: 10.1002/14651858.CD004383.pub2]

* Indicates the major publication for the study 
CHARACTERISTICS OF STUDIES

Characteristics of included studies [ordered by study ID]

Burke 1997

\begin{tabular}{ll} 
Methods & $\begin{array}{l}\text { Randomised controlled trial } \\
\text { Sample size calculation }\end{array}$ \\
\hline Participants & $\begin{array}{l}\text { Age children with chronic illness/physical disability for at least } 8 \text { months } \\
26 \text { boys ( } 52 \%), 24 \text { girls (48\%) }\end{array}$ \\
& Follow up 96\% at 3 months \\
\hline Interventions & Stress point intervention vs usual care \\
\hline Outcomes & Scales of Independent Behaviour \\
& Vernon Post-hospital Behaviour Questionnaire \\
& State-trait Anxiety Inventory \\
& Feetham Family Functioning Survey \\
& Coping Health Inventory for Parents \\
& 2 weeks and 3 months post intervention \\
\hline
\end{tabular}

Notes

\section{Risk of bias}

\begin{tabular}{|c|c|c|}
\hline Bias & Authors' judgement & Support for judgement \\
\hline $\begin{array}{l}\text { Random sequence genera- } \\
\text { tion (selection bias) }\end{array}$ & Unclear risk & Comment: Method of random sequence generation not mentioned. \\
\hline $\begin{array}{l}\text { Allocation concealment } \\
\text { (selection bias) }\end{array}$ & Low risk & $\begin{array}{l}\text { Quote; "A secretary blind to study details randomly assigned children to exper- } \\
\text { imental or control groups within age and diagnosis strata." }\end{array}$ \\
\hline $\begin{array}{l}\text { Blinding (performance } \\
\text { bias and detection bias) } \\
\text { All outcomes }\end{array}$ & Low risk & $\begin{array}{l}\text { Quote: " Participants, clinic staff, hospital staff and research assistants were } \\
\text { blind to group membership". }\end{array}$ \\
\hline $\begin{array}{l}\text { Blinding of participants } \\
\text { and personnel (perfor- } \\
\text { mance bias) } \\
\text { All outcomes }\end{array}$ & Low risk & As above \\
\hline $\begin{array}{l}\text { Blinding of outcome as- } \\
\text { sessment (detection bias) } \\
\text { All outcomes }\end{array}$ & Low risk & As above \\
\hline $\begin{array}{l}\text { Incomplete outcome data } \\
\text { (attrition bias) } \\
\text { All outcomes }\end{array}$ & Low risk & Comment: outcome data were reported for all participants. \\
\hline $\begin{array}{l}\text { Selective reporting (re- } \\
\text { porting bias) }\end{array}$ & Low risk & $\begin{array}{l}\text { Comment: outcome data were presented for all reported outcomes as mea- } \\
\text { sured. }\end{array}$ \\
\hline Other bias & Low risk & Comment: none were identified. \\
\hline
\end{tabular}


Dougherty 1998

\begin{tabular}{ll}
\hline Methods & $\begin{array}{l}\text { Randomised controlled trial } \\
\text { Intention-to-treat analysis not conducted }\end{array}$ \\
\hline Participants & $\begin{array}{l}63 \text { children with newly diagnosed insulin-dependent diabetes mellitus (IDDM) } \\
\text { Intervention group: mean age } 10.7 \text { yrs, } 13 \text { boys (41\%), } 19 \text { girls (59\%) } \\
\text { Control group: Usual care, mean } 9.8 \text { yrs, } 15 \text { boys (48\%), 16 girls (52\%). 100\% follow-up }\end{array}$ \\
\hline Interventions & Home and outpatient care for education and treatment of diabetes vs inpatient care \\
\hline Outcomes & Mean hours per child of service provision \\
Metabolic control \\
Knowledge, adherence and psychosocial effects \\
$\begin{array}{l}\text { Parental time and costs } \\
\text { Social cost effects } \\
\text { Diabetes-related adverse effects } \\
\text { Follow-up over } 24 \text { months }\end{array}$ \\
\hline
\end{tabular}

Notes

\section{Risk of bias}

\begin{tabular}{|c|c|c|}
\hline Bias & Authors' judgement & Support for judgement \\
\hline $\begin{array}{l}\text { Random sequence genera- } \\
\text { tion (selection bias) }\end{array}$ & Unclear risk & Comment: Method of random sequence generation not mentioned. \\
\hline $\begin{array}{l}\text { Allocation concealment } \\
\text { (selection bias) }\end{array}$ & Unclear risk & Comment: Allocation concealment details not mentioned. \\
\hline $\begin{array}{l}\text { Blinding (performance } \\
\text { bias and detection bias) } \\
\text { All outcomes }\end{array}$ & High risk & $\begin{array}{l}\text { Quote: " Although blinding of the patients, parents and treating team to treat- } \\
\text { ment group was impossible, they were blind to the aggregate group data } \\
\text { about patient characteristics, insulin treatment and clinical or psychosocial re- } \\
\text { sults during the study period." }\end{array}$ \\
\hline $\begin{array}{l}\text { Blinding of participants } \\
\text { and personnel (perfor- } \\
\text { mance bias) } \\
\text { All outcomes }\end{array}$ & High risk & As above \\
\hline $\begin{array}{l}\text { Blinding of outcome as- } \\
\text { sessment (detection bias) } \\
\text { All outcomes }\end{array}$ & Low risk & $\begin{array}{l}\text { Quote: "In addition, an independent evaluation team was responsible for all } \\
\text { data collection and analysis." }\end{array}$ \\
\hline $\begin{array}{l}\text { Incomplete outcome data } \\
\text { (attrition bias) } \\
\text { All outcomes }\end{array}$ & Low risk & Comment: outcome data were reported for all participants. \\
\hline $\begin{array}{l}\text { Selective reporting (re- } \\
\text { porting bias) }\end{array}$ & Low risk & $\begin{array}{l}\text { Comment: outcome data were presented for all outcomes reported as mea- } \\
\text { sured. }\end{array}$ \\
\hline Other bias & Low risk & Comment: none was identified. \\
\hline
\end{tabular}


Sartain 2001

\begin{tabular}{ll}
\hline Methods & $\begin{array}{l}\text { Randomised controlled trial } \\
\text { Sample size calculation } \\
\text { Intention-to-treat analysis conducted }\end{array}$ \\
\hline Participants & $\begin{array}{l}399 \text { children with acute paediatric illness (breathing difficulty, diarrhoea and vomiting or fever) } \\
\text { Median age } 13 \text { to } 15 \text { months (range } 6 \text { weeks to } 12 \text { years) }\end{array}$ \\
& $\begin{array}{l}240 \text { boys (60\%), } 159 \text { girls (40\%) } \\
100 \% \text { follow-up }\end{array}$ \\
\hline Interventions & 'Hospital at Home' vs usual inpatient paediatric care \\
\hline Outcomes & $\begin{array}{l}\text { Readmissions within } 90 \text { days of discharge } \\
\text { Length of stay } \\
\text { Qualitative assessment of parental and patient satisfaction } \\
\text { Cost effectiveness of both types of care }\end{array}$ \\
& Data collected over 17 months
\end{tabular}

Notes

\section{Risk of bias}

\begin{tabular}{|c|c|c|}
\hline Bias & Authors' judgement & Support for judgement \\
\hline $\begin{array}{l}\text { Random sequence genera- } \\
\text { tion (selection bias) }\end{array}$ & Low risk & $\begin{array}{l}\text { Quote: "Patients were randomised using a sealed numbered and opaque enve- } \\
\text { lope technique." }\end{array}$ \\
\hline $\begin{array}{l}\text { Allocation concealment } \\
\text { (selection bias) }\end{array}$ & Low risk & As above \\
\hline $\begin{array}{l}\text { Blinding (performance } \\
\text { bias and detection bias) } \\
\text { All outcomes }\end{array}$ & High risk & $\begin{array}{l}\text { Comment: It is unlikely that participants and personnel were blinded to inter- } \\
\text { vention measures of "hospital at home care" vs "conventional hospital care" } \\
\text { in this study. }\end{array}$ \\
\hline $\begin{array}{l}\text { Blinding of participants } \\
\text { and personnel (perfor- } \\
\text { mance bias) } \\
\text { All outcomes }\end{array}$ & High risk & As above \\
\hline $\begin{array}{l}\text { Blinding of outcome as- } \\
\text { sessment (detection bias) } \\
\text { All outcomes }\end{array}$ & Unclear risk & $\begin{array}{l}\text { Comment: The independent clinician verified the diagnoses for all participants } \\
\text { readmitted but it is unclear whether all study data were assessed by indepen- } \\
\text { dent researchers. }\end{array}$ \\
\hline $\begin{array}{l}\text { Incomplete outcome data } \\
\text { (attrition bias) } \\
\text { All outcomes }\end{array}$ & High risk & $\begin{array}{l}\text { Comment: The qualitative data collection included a purposive sample of } 40 \\
\text { families which is } 1 / 10 \text { th of the total study population. }\end{array}$ \\
\hline $\begin{array}{l}\text { Selective reporting (re- } \\
\text { porting bias) }\end{array}$ & Low risk & $\begin{array}{l}\text { Comment: outcome data were presented for all outcomes reported as mea- } \\
\text { sured. }\end{array}$ \\
\hline Other bias & Low risk & Comment: none was identified. \\
\hline
\end{tabular}

Stein 1984

Methods Randomised controlled trial


Stein 1984 (Continued)

Set in USA

Intention-to-treat analysis not conducted

\section{Participants}

219 children (age below 11 years) with diverse range of chronic conditions (defined as presence of a physical condition for more than 3 months; children with moderate to severe mental retardation excluded).

$85 \%$ follow-up at 6 months, $83 \%$ follow-up at 1 year.

\begin{tabular}{ll}
\hline Interventions & Paediatric home care vs standard care \\
\hline Outcomes & Satisfaction with care \\
& Child's psychological adjustment \\
Mother's psychiatric symptoms \\
Impact on family \\
Functional status measure \\
Data collected at enrolment, 6 months and 1 year
\end{tabular}

\section{Notes}

\section{Risk of bias}

\begin{tabular}{|c|c|c|}
\hline Bias & Authors' judgement & Support for judgement \\
\hline $\begin{array}{l}\text { Random sequence genera- } \\
\text { tion (selection bias) }\end{array}$ & Low risk & $\begin{array}{l}\text { Quote: "This was done using opaque sealed envelopes prepared in sets by a } \\
\text { roll of dice to determine the order of the first assignment." }\end{array}$ \\
\hline $\begin{array}{l}\text { Allocation concealment } \\
\text { (selection bias) }\end{array}$ & Low risk & $\begin{array}{l}\text { Quote: "All scoring and randomisation procedures were carried out by a mem- } \\
\text { ber of the research staff independently of the clinicians, and the responsible } \\
\text { clinician was notified of the group assignment." }\end{array}$ \\
\hline $\begin{array}{l}\text { Blinding (performance } \\
\text { bias and detection bias) } \\
\text { All outcomes }\end{array}$ & High risk & $\begin{array}{l}\text { Quote: "Because of the nature of the intervention and likelihood of discovering } \\
\text { group assignment during data collection, no attempt was made for patients, } \\
\text { physicians or interviewers to be blind to group assignment." }\end{array}$ \\
\hline $\begin{array}{l}\text { Blinding of participants } \\
\text { and personnel (perfor- } \\
\text { mance bias) } \\
\text { All outcomes }\end{array}$ & High risk & As above \\
\hline $\begin{array}{l}\text { Blinding of outcome as- } \\
\text { sessment (detection bias) } \\
\text { All outcomes }\end{array}$ & High risk & As above \\
\hline $\begin{array}{l}\text { Incomplete outcome data } \\
\text { (attrition bias) } \\
\text { All outcomes }\end{array}$ & High risk & $\begin{array}{l}\text { Quote: " A complete data set of all three interviews exists on } 174 \text { subjects or } \\
80 \% \text { of all subjects." }\end{array}$ \\
\hline $\begin{array}{l}\text { Selective reporting (re- } \\
\text { porting bias) }\end{array}$ & Low risk & $\begin{array}{l}\text { Comment: outcome data were presented for all outcomes reported as mea- } \\
\text { sured. }\end{array}$ \\
\hline Other bias & Low risk & Comment: none was identified. \\
\hline
\end{tabular}


Stevens 2006 (Continued)
Participants
2 to 16 year age group
29 children with acute lymphoblastic leukaemia (ALL) in the year prior to enrolment in study
15 allocated to home and then hospital chemotherapy and 14 vice versa
Total 23 children received allocated treatment
6 children discontinued intervention or relapsed

Interventions $\quad$ Comparison of home-based with hospital-based chemotherapy
At home, chemotherapy administered by a trained nurse

Child's quality of life (QOL)
Effects on parental caregivers
Adverse effects
Costs
$\begin{aligned} & \text { Data assessed at baseline, } 3 \text { months (postphase 1), } 6 \text { months (postphase 1), } 3 \text { months (postphase 2) } \\ & \text { and } 6 \text { months (postphase 2) }\end{aligned}$

Cross-over study with no time gap between cross-over of two study arms

\section{Risk of bias}

\begin{tabular}{|c|c|c|}
\hline Bias & Authors' judgement & Support for judgement \\
\hline $\begin{array}{l}\text { Random sequence genera- } \\
\text { tion (selection bias) }\end{array}$ & Low risk & $\begin{array}{l}\text { Quote: " Using a table of random numbers, eligible children were randomly } \\
\text { assigned by the study site manager to either the hospital (standard care) or } \\
\text { home (treatment) chemotherapy group for phase } 1 \text { ( } 6 \text { months)." }\end{array}$ \\
\hline $\begin{array}{l}\text { Allocation concealment } \\
\text { (selection bias) }\end{array}$ & Unclear risk & Comment: the allocation concealment is not mentioned. \\
\hline $\begin{array}{l}\text { Blinding (performance } \\
\text { bias and detection bias) } \\
\text { All outcomes }\end{array}$ & High risk & $\begin{array}{l}\text { Comment: The study method implies that blinding of neither participants nor } \\
\text { clinicians was possible. }\end{array}$ \\
\hline $\begin{array}{l}\text { Blinding of participants } \\
\text { and personnel (perfor- } \\
\text { mance bias) } \\
\text { All outcomes }\end{array}$ & High risk & As above \\
\hline $\begin{array}{l}\text { Blinding of outcome as- } \\
\text { sessment (detection bias) } \\
\text { All outcomes }\end{array}$ & Unclear risk & $\begin{array}{l}\text { Comment: Not mentioned whether data were analysed by independent clini- } \\
\text { cians blinded to the outcome assessment. }\end{array}$ \\
\hline $\begin{array}{l}\text { Incomplete outcome data } \\
\text { (attrition bias) } \\
\text { All outcomes }\end{array}$ & Low risk & Comment: outcome data were reported for all participants. \\
\hline $\begin{array}{l}\text { Selective reporting (re- } \\
\text { porting bias) }\end{array}$ & Low risk & $\begin{array}{l}\text { Comment: outcome data were presented for all outcomes reported as mea- } \\
\text { sured. }\end{array}$ \\
\hline Other bias & Low risk & Comment: none were identified. \\
\hline
\end{tabular}

\section{Strawczynski 1973}

Methods Quasi-randomised controlled trial


Strawczynski 1973 (Continued)

\begin{tabular}{|c|c|}
\hline Participants & $\begin{array}{l}40 \text { children with haemophilia } \\
2 \text { to } 15 \text { years of age } \\
90 \% \text { follow-up }\end{array}$ \\
\hline Interventions & Home care for bleeds vs hospital \\
\hline Outcomes & $\begin{array}{l}\text { Number of bleeds } \\
\text { Total number of treatment days } \\
\text { Procrastination time } \\
\text { School attendance } \\
\text { Days in hospital } \\
\text { Costs }\end{array}$ \\
\hline & Duration 2 years \\
\hline
\end{tabular}

\section{Notes}

\section{Risk of bias}

\begin{tabular}{lll}
\hline Bias & Authors' judgement & Support for judgement \\
\hline $\begin{array}{l}\text { Random sequence genera- } \\
\text { tion (selection bias) }\end{array}$ & High risk & $\begin{array}{l}\text { Quote: "The patients were assigned to alternate groups when they presented } \\
\text { with their first bleeding episode." }\end{array}$ \\
\hline $\begin{array}{l}\text { Allocation concealment } \\
\text { (selection bias) }\end{array}$ & High risk & $\begin{array}{l}\text { Comment: alternate group allocation would allow prediction of the allocation } \\
\text { sequence. }\end{array}$ \\
\hline $\begin{array}{l}\text { Blinding (performance } \\
\text { bias and detection bias) } \\
\text { All outcomes }\end{array}$ & High risk & $\begin{array}{l}\text { Comment: The study method implies that blinding of neither participants or } \\
\text { clinicians was possible. }\end{array}$ \\
\hline $\begin{array}{l}\text { Blinding of participants } \\
\text { and personnel (perfor- } \\
\text { mance bias) }\end{array}$ & High risk & As above \\
\begin{tabular}{l} 
All outcomes \\
\hline
\end{tabular} &
\end{tabular}

\begin{tabular}{lll}
$\begin{array}{l}\text { Blinding of outcome as- } \\
\text { sessment (detection bias) } \\
\text { All outcomes }\end{array}$ & Unclear risk & $\begin{array}{l}\text { Comment: Not mentioned whether data was analysed by independent clini- } \\
\text { cians blinded to the outcome assessment. }\end{array}$ \\
\hline $\begin{array}{l}\text { Incomplete outcome data } \\
\text { (attrition bias) } \\
\text { All outcomes }\end{array}$ & Low risk & Comment: outcome data were reported for all participants. \\
\hline $\begin{array}{l}\text { Selective reporting (re- } \\
\text { porting bias) }\end{array}$ & Low risk & $\begin{array}{l}\text { Comment: outcome data were presented for all outcomes reported as mea- } \\
\text { sured. }\end{array}$ \\
\hline Other bias & Low risk & Comment: none was identified. \\
\hline
\end{tabular}

Tie 2009

\begin{tabular}{ll}
\hline Methods & Prospective randomised controlled trial, pilot study \\
\hline Participants & $\begin{array}{l}44 \text { out of } 58 \text { eligible children with acute bronchiolitis enrolled } \\
\text { Age group } 3 \text { to } 24 \text { months } \\
\text { Oxygen saturation on arrival }>92 \% \text { in both groups }\end{array}$
\end{tabular}


Tie 2009 (Continued)

Observed and clinically stable for $>24 \mathrm{hrs}$ in hospital

$100 \%$ follow-up

\begin{tabular}{ll}
\hline Interventions & Home oxygen therapy vs hospital care \\
\hline Outcomes & $\begin{array}{l}\text { Readmission to hospital within } 7 \text { days of discharge home } \\
\text { Total duration of hospitalisation }\end{array}$
\end{tabular}

Notes

\section{Risk of bias}

\begin{tabular}{|c|c|c|}
\hline Bias & Authors' judgement & Support for judgement \\
\hline $\begin{array}{l}\text { Random sequence genera- } \\
\text { tion (selection bias) }\end{array}$ & Unclear risk & Comment: The method of random sequence generation not mentioned. \\
\hline $\begin{array}{l}\text { Allocation concealment } \\
\text { (selection bias) }\end{array}$ & Low risk & $\begin{array}{l}\text { Quote: "Researchers were blinded and only following informed consent was } \\
\text { the management allocation revealed." }\end{array}$ \\
\hline $\begin{array}{l}\text { Blinding (performance } \\
\text { bias and detection bias) } \\
\text { All outcomes }\end{array}$ & High risk & $\begin{array}{l}\text { Comment: The nature of study intervention, 'hospital in the home' vs tradi- } \\
\text { tional hospitalisation indicates that blinding of participants or clinicians was } \\
\text { not possible. }\end{array}$ \\
\hline $\begin{array}{l}\text { Blinding of participants } \\
\text { and personnel (perfor- } \\
\text { mance bias) } \\
\text { All outcomes }\end{array}$ & High risk & As above \\
\hline $\begin{array}{l}\text { Blinding of outcome as- } \\
\text { sessment (detection bias) } \\
\text { All outcomes }\end{array}$ & Unclear risk & $\begin{array}{l}\text { Coment: Not mentioned whether data were analysed by independent clini- } \\
\text { cians blinded to the outcome assessment. }\end{array}$ \\
\hline $\begin{array}{l}\text { Incomplete outcome data } \\
\text { (attrition bias) } \\
\text { All outcomes }\end{array}$ & Low risk & Comment: outcome data were reported for all participants. \\
\hline $\begin{array}{l}\text { Selective reporting (re- } \\
\text { porting bias) }\end{array}$ & Low risk & $\begin{array}{l}\text { Comment: outcome data were presented for all outcomes reported as mea- } \\
\text { sured. }\end{array}$ \\
\hline Other bias & Low risk & Comment: none was identified. \\
\hline
\end{tabular}

\section{Characteristics of excluded studies [ordered by study ID]}

\begin{tabular}{ll}
\hline Study & Reason for exclusion \\
\hline Affleck 1989 & Home support rather than specialist home-based nursing \\
\hline Alexander 1988 & Clinic-based intervention \\
\hline Badr 2006 & Parental education by nurses (not home-based nursing) \\
\hline Bang 1999 & Community-based health visitor trial \\
\hline Beckwith 1988 & Home support rather than specialist home-based nursing \\
\hline \hline
\end{tabular}




\begin{tabular}{|c|c|}
\hline Study & Reason for exclusion \\
\hline Black 1995 & Home visitors for non-organic failure to thrive \\
\hline Blakeslee 1997 & Non-randomised comparison study \\
\hline Brooten 1986 & Low birth weight is not an acute or chronic illness \\
\hline Brown 2002 & Asthma education (not home-based nursing) \\
\hline Broyles 2000 & Clinic-based intervention \\
\hline Butz 1994 & Asthma education (not home-based nursing) \\
\hline Butz 2006 & Asthma education (not home-based nursing) \\
\hline Caliskan Yilmaz 2010 & Quasi-experimental study design (no randomisation) \\
\hline Casiro 1993 & Low birth weight is not an acute or chronic illness \\
\hline Catov 2005 & $\begin{array}{l}\text { Asthma education (not home-based nursing) } \\
\text { Quasi-experimental design (non-randomised) }\end{array}$ \\
\hline Crowin 2005 & $\begin{array}{l}\text { Age group } 16 \text { years and older with no details available of study participants aged between } 16 \text { and } \\
18 \text { age. Authors contacted but no response received }\end{array}$ \\
\hline Deaves 1993 & Asthma education (not home-based nursing) \\
\hline Dolinar 2000 & Asthma education (not home-based nursing) \\
\hline Donati 1987 & Non-randomised comparison study \\
\hline Greineder 1999 & Asthma education (not home-based nursing) \\
\hline Hatziagorou 2010 & Not a randomised controlled trial \\
\hline Heikens 1994 & Community health aides for protein calorie malnutrition \\
\hline Hughes 1991 & Asthma education (not home-based nursing) \\
\hline Keefe 2006 & Parent education programme (not home-based nursing) \\
\hline Krieger 2009 & Asthma education (not home-based nursing) \\
\hline Lindberg 2002 & Non-randomised comparison study \\
\hline Madge 1997 & Asthma education (not home-based nursing) \\
\hline McConnochie 1999 & Asthma education (not home-based nursing) \\
\hline Mitchell 1986 & Asthma education (not home-based nursing) \\
\hline Park 2002 & Non-randomised comparison study \\
\hline Raynor 1999 & Specialist health visitor for non-organic failure to thrive \\
\hline Rieger 1995 & Non-randomised comparison study \\
\hline
\end{tabular}




\begin{tabular}{ll}
\hline Study & Reason for exclusion \\
\hline Schuttelaar 2010 & Nurse practitioner care in the hospital outpatient clinic, no home-based treatment \\
\hline Shin 2009 & Parental education for early intervention (not home-based nursing) \\
\hline Svahn 2002 & Non randomised comparison study, inappropriate age group \\
\hline Svahn 2008 & Non-randomised comparison study \\
\hline Talabere 1993 & Asthma education (not home-based nursing) \\
\hline Tiberg 2011 & Home care in hospital grounds, not home-based care \\
\hline Wang 1995 & Presurgery assessments, not home nursing \\
\hline Wolter 1997 & Participants with cystic fibrosis give their own therapy - no nurses \\
\hline Wright 1998 & Home visitors for non-organic failure to thrive \\
\hline
\end{tabular}

\section{ADDITIONAL TABLES}

Table 1. Characteristics of interventions showing diversity of services

\begin{tabular}{|c|c|c|c|c|c|c|}
\hline Study & $\begin{array}{l}\text { Study set- } \\
\text { tings }\end{array}$ & $\begin{array}{l}\text { Type of illness } \\
\text { - intervention }\end{array}$ & $\begin{array}{l}\text { Hours } \\
\text { Available }\end{array}$ & $\begin{array}{l}\text { No. visits possi- } \\
\text { ble }\end{array}$ & $\begin{array}{l}\text { Staff Qualifica- } \\
\text { tions }\end{array}$ & Information provided \\
\hline Burke 1997 & $\begin{array}{l}\text { Queen's Uni- } \\
\text { versity, Uni- } \\
\text { versity of } \\
\text { Toronto, On- } \\
\text { tario, Canada }\end{array}$ & $\begin{array}{l}\text { Children with } \\
\text { chronic condi- } \\
\text { tions - stress- } \\
\text { point interven- } \\
\text { tion for parents }\end{array}$ & $\begin{array}{l}\text { Not report- } \\
\text { ed. } \\
\text { Direct } \\
\text { phone con- } \\
\text { tact with } \\
\text { nurse } \\
\text { related } \\
\text { to 'stres- } \\
\text { sors' rather } \\
\text { than clini- } \\
\text { cal events. }\end{array}$ & Not reported. & $\begin{array}{l}\text { "master's pre- } \\
\text { pared nurse". }\end{array}$ & $\begin{array}{l}\text { Mailed summaries and } \\
\text { reminders of families } \\
\text { own stress points and } \\
\text { coping strategies. }\end{array}$ \\
\hline $\begin{array}{l}\text { Dougherty } \\
1998\end{array}$ & $\begin{array}{l}\text { The Montre- } \\
\text { al Children's } \\
\text { Hospital, Mon- } \\
\text { treal, Quebec, } \\
\text { Canada }\end{array}$ & $\begin{array}{l}\text { Newly diag- } \\
\text { nosed children } \\
\text { with IDDM - } \\
\text { Home based } \\
\text { treatment }\end{array}$ & $\begin{array}{l}24 \text { hour } \\
\text { telephone } \\
\text { consulta- } \\
\text { tion. }\end{array}$ & $\begin{array}{l}\text { Home visits once/ } \\
\text { twice daily for first } \\
2 \text { - } 3 \text { days, teach- } \\
\text { ing visit at clin- } \\
\text { ic after } 2 \text { weeks, } \\
\text { follow-up outpa- } \\
\text { tient visits at } 2 \text { - } 3 \\
\text { months. }\end{array}$ & $\begin{array}{l}\text { Diabetes treat- } \\
\text { ment nurse, } \\
\text { as part of a } \\
\text { team of dia- } \\
\text { betes-specialist } \\
\text { physician, psy- } \\
\text { chologist and } \\
\text { social worker. }\end{array}$ & $\begin{array}{l}\text { Teaching session, in- } \\
\text { struction and supervision } \\
\text { in practical and theoreti- } \\
\text { cal aspects of treatment. }\end{array}$ \\
\hline $\begin{array}{l}\text { Sartain } \\
2001\end{array}$ & $\begin{array}{l}\text { Arrow Park } \\
\text { Hospital, Up- } \\
\text { ton, Wirral, UK }\end{array}$ & $\begin{array}{l}\text { Acute illness } \\
\text { (breathing diffi- } \\
\text { culty, diarrhoea } \\
\text { and vomiting } \\
\text { or fever) - Hos- } \\
\text { pital at home }\end{array}$ & $\begin{array}{l}24 \text { hours, } 7 \\
\text { days. Ser- } \\
\text { vice un- } \\
\text { til } 2300 \text {, } \\
\text { on-call } \\
\text { overnight. }\end{array}$ & 1 - 4 daily & $\begin{array}{l}\text { Not specified. } \\
\text { Participants } \\
\text { under care of } \\
\text { hospital consul- } \\
\text { tants. }\end{array}$ & $\begin{array}{l}\text { Patient information } \\
\text { booklets detailing pos- } \\
\text { sible course of illness, } \\
\text { signs and symptoms of } \\
\text { potential deterioration, } \\
\text { appropriate treatment, } \\
\text { contact information. }\end{array}$ \\
\hline
\end{tabular}


Table 1. Characteristics of interventions showing diversity of services (Continued)

scheme treat-

ment

\begin{tabular}{|c|c|c|c|c|c|c|}
\hline Stein 1984 & $\begin{array}{l}\text { Paediatric } \\
\text { Ambulatory } \\
\text { Care Division, } \\
\text { Albert Ein- } \\
\text { stein College } \\
\text { of Medicine, } \\
\text { Bronx, New } \\
\text { York }\end{array}$ & $\begin{array}{l}\text { Heteroge- } \\
\text { nous group of } \\
\text { children with } \\
\text { chronic illness- } \\
\text { es - Paediatric } \\
\text { home care }\end{array}$ & $\begin{array}{l}\text { Not speci- } \\
\text { fied. }\end{array}$ & $\begin{array}{l}\text { Minimum pack- } \\
\text { age: initial home } \\
\text { visit, one con- } \\
\text { tact (by person } \\
\text { or by telephone) } \\
\text { each month for } 6 \\
\text { months. Most par- } \\
\text { ticipants received } \\
\text { more. }\end{array}$ & $\begin{array}{l}\text { Team of gen- } \\
\text { eralist paedi- } \\
\text { atricians, pae- } \\
\text { diatric nurse } \\
\text { practition- } \\
\text { ers and social } \\
\text { worker. }\end{array}$ & $\begin{array}{l}\text { "Teach child and fami- } \\
\text { ly about condition and } \\
\text { train them in self-care } \\
\text { skills". }\end{array}$ \\
\hline $\begin{array}{l}\text { Stevens } \\
2006\end{array}$ & $\begin{array}{l}\text { University of } \\
\text { Toronto and } \\
\text { Sick Kid's Hos- } \\
\text { pital, Toronto, } \\
\text { Canada }\end{array}$ & $\begin{array}{l}\text { Children with } \\
\text { acute lym- } \\
\text { phoblastic } \\
\text { leukemia } \\
\text { - Home } \\
\text { chemotherapy }\end{array}$ & $\begin{array}{l}\text { Not speci- } \\
\text { fied. }\end{array}$ & $\begin{array}{l}\text { Home visits for } \\
\text { administration of } \\
\text { chemotherapy as } \\
\text { per the protocol. }\end{array}$ & $\begin{array}{l}\text { Trained nurse } \\
\text { from a commu- } \\
\text { nity health ser- } \\
\text { vices agency } \\
\text { administered } \\
\text { chemotherapy, } \\
\text { routine contact } \\
\text { by community } \\
\text { nurse to the on- } \\
\text { cologist if con- } \\
\text { cerns. }\end{array}$ & $\begin{array}{l}\text { Parents encouraged to } \\
\text { contact primary nurse at } \\
\text { the oncology clinic at the } \\
\text { hospital as required }\end{array}$ \\
\hline $\begin{array}{l}\text { Strawczyn- } \\
\text { ski } 1973\end{array}$ & $\begin{array}{l}\text { The Montre- } \\
\text { al Children's } \\
\text { Hospital, Mon- } \\
\text { treal, Quebec, } \\
\text { Canada }\end{array}$ & $\begin{array}{l}\text { Management of } \\
\text { bleeding in he- } \\
\text { mophilic chil- } \\
\text { dren }\end{array}$ & $\begin{array}{l}\text { 24-hour } \\
\text { service } \\
\text { when in- } \\
\text { cident } \\
\text { (bleed- } \\
\text { ing in chil- } \\
\text { dren with } \\
\text { haemophil- } \\
\text { ia) oc- } \\
\text { curred. }\end{array}$ & Not specified. & $\begin{array}{l}\text { Specially } \\
\text { trained nurse. }\end{array}$ & $\begin{array}{l}\text { No educational interven- } \\
\text { tion reported. }\end{array}$ \\
\hline Tie 2009 & $\begin{array}{l}\text { Department } \\
\text { of General } \\
\text { Paediatrics, } \\
\text { Princess Mar- } \\
\text { garet Hospital } \\
\text { for children, } \\
\text { Perth, West- } \\
\text { ern Australia }\end{array}$ & $\begin{array}{l}\text { Acute bronchi- } \\
\text { olitis - home } \\
\text { oxygen therapy }\end{array}$ & $\begin{array}{l}\text { Not speci- } \\
\text { fied }\end{array}$ & $\begin{array}{l}\text { "Hospital in the } \\
\text { home (HiTH)" } \\
\text { nurse home vis- } \\
\text { it within } 12 \text { hours } \\
\text { of hospital dis- } \\
\text { charge, minimum } \\
\text { of } 2 \text { home visits, } \\
\text { one phone con- } \\
\text { tact with parents } \\
\text { in every } 24 \text {-hour } \\
\text { period. }\end{array}$ & Not specified. & $\begin{array}{l}\text { Parents were educated } \\
\text { on home oxygen use and } \\
\text { instructed on how to ob- } \\
\text { serve their children for } \\
\text { signs of clinical deterio- } \\
\text { ration. }\end{array}$ \\
\hline
\end{tabular}

\section{AP PE N DICES}

\section{Appendix 1. Search strategies February 2012}

Cochrane Central Register of Controlled Trials (CENTRAL), part of the Cochrane Library, 2012 (Issue 1), searched 9 February 2012

\#1MeSH descriptor: [Home Care Services] 1 tree(s) exploded

\#2MeSH descriptor: [Nurse Clinicians] this term only

\#3MeSH descriptor: [Community Health Nursing] this term only 
\#4MeSH descriptor: [Nurse Practitioners] this term only \#5MeSH descriptor: [Home Nursing] 3 tree(s) exploded \#6((home or homebased or domicil $\left.{ }^{\star}\right)$ near/3 treat*):ti,ab,kw \#7((home or homebased or domicil $\left.{ }^{\star}\right)$ near/3 (care or caring)):ti,ab,kw \#8((home or homebased or domicil $\left.{ }^{\star}\right)$ near/3 healthcar $\left.{ }^{\star}\right)$ :ti,ab,kw \#9(nursing near/3 outreach):ti,ab,kw \#10((paediatric or pediatric) near/3 ambulat $\left.{ }^{\star}\right): t i, a b, k w$

$\# 11$ ((home or home based or domicil $\left.{ }^{\star}\right)$ near/3 nurs $\left.{ }^{\star}\right)$

\#12(hospital near/3 home):ti,ab,kw

$\# 13 \# 1$ or \#2 or \#3 or \#4 or \#5 or \#6 or \#7 or \#8 or \#9 or \#10 or \#11 or \#12

$\# 14$ (baby or babies or infant ${ }^{\star}$ or toddler ${ }^{\star}$ or child ${ }^{\star}$ or preschool ${ }^{\star}$ or pre next school ${ }^{\star}$ or teen $^{\star}$ or adolescen ${ }^{\star}$ :ti,ab,kw \#15MeSH descriptor: [Child] 1 tree(s) exploded

\#16MeSH descriptor: [Infant] 1 tree(s) exploded

$\# 17 \mathrm{MeSH}$ descriptor: [Adolescent] this term only

\#18\#14 or \#15 or \#16 or \#17

$\# 19 \# 13$ and \#18

\section{Ovid MEDLINE 1946 to Jan Week 4 2012, searched 8 February 2012}

1 exp Home Care Services/ (36908)

2 Home Care Services, Hospital-Based/ (1474)

3 Community Health Nursing/ (17645)

4 nurse clinicians/ (7117)

5 nurse practitioners/ (14200)

6 exp home nursing/ (8281)

7 ((home or homebased or domicil\$) adj3 treat\$).tw. (3333)

8 ((home or homebased or domicil\$) adj3 (care\$ or caring)).tw. (18937)

9 ((home or homebased or domicil\$) adj3 healthcar\$).tw. (835)

10 (nursing adj3 outreach).tw. (55)

11 (p?ediatric adj3 ambulatory\$).tw. (496)

12 ((home or homebased or domicil\$) adj3 nurs\$).tw. (17291)

13 (hospital adj3 home).tw. (3967)

14 or/1-13 (92524)

15 exp Infant/ (856559)

16 exp child/ (1405066)

17 adolescent/ (1440129)

18 (baby or babies or infant\$ or toddler\$ or child\$ or preschool\$ or pre-school\$ or teen\$ or adolescen\$).tw. (1125366)

19 or/15-18 (2771225)

20 randomized controlled trial.pt. (317638)

21 controlled clinical trial.pt. (83333)

22 randomi\#ed.ab. (266278)

23 placebo\$.ab. (128230)

24 drug therapy.fs. (1495532)

25 randomly.ab. (161461)

26 trial.ab. (229896)

27 groups.ab. (1067026)

28 or/20-27 (2777450)

29 exp animals/ not humans.sh. (3647344)

3028 not 29 (2358297)

3114 and 19 and 30 (2971)

32 limit 31 to $y r=" 2005$-Current" (1009)

\section{EMBASE (Ovid), 1980 to 2012 Week 05, searched 9 February 2012}

1 exp home care/ (46930)

2 community health nursing/ (24600)

3 exp nurse practitioner/ (15820)

4 ((home or homebased or domicil\$) adj3 treat\$).tw. (4377)

5 ((home or homebased or domicil\$) adj3 (care\$ or caring)).tw. (21637)

6 ((home or homebased or domicil\$) adj3 healthcar\$).tw. (900)

7 (nursing adj3 outreach).tw. (70)

8 (p?ediatric adj3 ambulatory\$).tw. (841)

9 ((home or homebased or domicil\$) adj3 nurs\$).tw. (20285)

Specialist home-based nursing services for children with acute and chronic illnesses (Review) 
10 (hospital adj3 home).tw. (4760)

11 or/1-10 (108582)

12 exp child/ (1518691)

13 exp adolescent/ (1132793)

14 (baby or babies or infant\$ or toddler\$ or child\$ or preschool\$ or pre-school\$ or teen\$ or adolescen\$).tw. (1316929)

1512 or 13 or 14 (2508849)

1611 and 15 (16654)

17 exp Clinical trial/ (880196)

18 Randomized controlled trial/ (296765)

19 Randomization/ (55652)

20 Single blind procedure/ (14775)

21 Double blind procedure/ (102866)

22 Crossover procedure/ (31796)

23 Placebo/ (192025)

24 Randomi\#ed.tw. (372082)

25 RCT.tw. (8444)

26 (random\$ adj3 (allocat\$ or assign\$)).tw. (88417)

27 randomly.ab. (203108)

28 groups.ab. (1321946)

29 trial.ab. (293317)

30 ((singl\$ or doubl\$ or trebl\$ or tripl\$) adj3 (blind\$ or mask\$)).tw. (135186)

31 Placebo\$.tw. (164757)

32 Prospective study/ (181795)

33 (crossover or cross-over).tw. (57030)

34 prospective.tw. (350288)

35 or/17-34 (2628978)

3616 and 35 (2991)

37 limit 36 to $y r=" 2005$-Current" (1335)

PsycINFO (Ovid) 1806 to Feb Week 1 2012, searched 9 February 2012

1 home care/ (3786)

2 ((home or homebased or domicil\$) adj3 treat\$).tw. (1198)

3 ((home or homebased or domicil\$) adj3 (care\$ or caring)).tw. (6838)

4 ((home or homebased or domicil\$) adj3 healthcar\$).tw. (84)

5 (nursing adj3 outreach).tw. (18)

6 ((home or homebased or domicil\$) adj3 nurs\$).tw. (7345)

7 (hospital adj3 home).tw. (912)

8 (p?ediatric adj3 ambulatory\$).tw. (40)

9 (nurse adj3 (specialist\$ or practitioner or clinican)).tw. (1067)

10 or/1-9 (16351)

11 (adolescence 1317 yrs or childhood birth 12 yrs).ag. (527933)

12 (baby or babies or infant\$ or toddler\$ or child\$ or preschool\$ or pre-school\$ or teen\$ or adolescen\$).tw. (609887)

1311 or $12(767428)$

14 clinical trials/ (5796)

15 (randomis\$ or randomiz\$).tw. (35991)

16 (random\$ adj3 (allocat\$ or assign\$)).tw. (25127)

17 ((clinic\$ or control\$) adj trial\$).tw. (30613)

18 ((singl\$ or doubl\$ or trebl\$ or tripl\$) adj3 (blind\$ or mask\$)).tw. (17112)

19 (crossover\$ or "cross over\$").tw. (5899)

20 random sampling/ (527)

21 Experiment Controls/ (636)

22 Placebo/ (3125)

23 placebo\$.tw. (27173)

24 exp program evaluation/ (14599)

25 treatment effectiveness evaluation/ (13106)

26 ((effectiveness or evaluat\$) adj3 (stud\$ or research\$)).tw. (46630)

27 or/14-26 (151249)

2810 and 13 and 27 (293)

29 limit 28 to $y r=" 2005$-Current" (143)

CINAHL Plus (EBSCOhost), 1937 to current, searched 9 February 2012 
S34 S17 and S32

S33 S17 and S32

$\mathrm{S} 32 \mathrm{~S} 18$ or $\mathrm{S} 19$ or $\mathrm{S} 20$ or $\mathrm{S} 21$ or $\mathrm{S} 22$ or $\mathrm{S} 23$ or $\mathrm{S} 24$ or $\mathrm{S} 25$ or $\mathrm{S} 26$ or $\mathrm{S} 27$ or

$\mathrm{S} 28$ or S29 or S30 or S31

S31 TI (evaluat* study or evaluat* research) or AB (evaluate* study or

evaluat* research) or TI (effectiv* study or effectiv* research) or AB (effectiv* study or effectiv* research) OR TI (prospectiv* study or prospectiv* research) or $\mathrm{AB}$ (prospectiv* study or prospectiv* research) or TI (follow-up study or follow-up research) or $\mathrm{AB}$ (follow-up study or follow-up research)

S30 placebo*

S29 crossover* or "cross over"

S28 (MH "Crossover Design")

S27 (tripl* N3 mask $\left.{ }^{\star}\right)$ or (tripl* N3 blind $\left.{ }^{\star}\right)$

S26 (trebl* N3 mask ${ }^{\star}$ ) or (trebl* N3 blind $\left.{ }^{\star}\right)$

S25 (doubl* N3 mask*) or (doubl* N3 blind $\left.{ }^{\star}\right)$

S24 (singl ${ }^{\star}$ N3 mask $^{\star}$ ) or $\left(\right.$ singl ${ }^{\star}$ N3 blind $\left.{ }^{\star}\right)$

S23 (clinic ${ }^{*}$ N3 trial $^{*}$ ) or (control* N3 trial*)

S22 (random* N3 allocat* ) or (random* N3 assign*)

S21 randomis ${ }^{\star}$ or randomiz*

S20 (MH "Meta Analysis")

S19 (MH "Clinical Trials+")

S18 $\mathrm{MH}$ random assignment

S17 S11 and S16

S16 S13 or S14 S15

S15 (baby or babies or infant ${ }^{\star}$ or toddler ${ }^{\star}$ or child ${ }^{\star}$ or preschool ${ }^{\star}$ or pre-school ${ }^{\star}$ or teen ${ }^{\star}$ or adolescen ${ }^{\star}$ )

S14 (MH "Adolescence")

S13 (MH "Child") OR (MH "Child, Preschool") OR (MH "Infant+")

S12 infant

$\mathrm{S} 11 \mathrm{~S} 1$ or $\mathrm{S} 2$ or $\mathrm{S} 3$ or $\mathrm{S} 4$ or $\mathrm{S} 5$ or $\mathrm{S} 6$ or $\mathrm{S} 7$ or $\mathrm{S} 8$ or $\mathrm{S} 9$ or $\mathrm{S} 10$

S10 (hospital N3 home)

S9 ((home or homebased or domicil $\left.{ }^{\star}\right)$ N3 nurs $\left.{ }^{\star}\right)$

S8 (p\#ediatric N3 ambulatory)

S7 (nursing N3 outreach)

S6 ((home or homebased or domicil $\left.{ }^{\star}\right)$ N3 healthcar $\left.{ }^{\star}\right)$

S5 ((home or homebased or domicil $\left.{ }^{\star}\right)$ N3 (care* or caring))

S4 ((home or homebased or domicil $\left.{ }^{\star}\right)$ N3 treat $^{\star}$ )

S3 (MH "Advanced Practice Nurses+")

S2 (MH "Community Health Nursing+") OR (MH "Ambulatory Care Nursing") OR (MH"Specialties, Nursing")

S1 (MH "Home Health Care+")

\section{Sociological Abstracts (Proquest) 1952 to current, searched 9 February 2012}

(SU.EXACT("Home Health Care") OR AB((home OR homebased OR domicil*) NEAR/3 treat*)

OR TI((home OR homebased OR domicil*) NEAR/3 treat $\left.{ }^{\star}\right)$ OR AB((home OR homebased OR

domicil $^{\star}$ ) NEAR/3 (care* OR caring)) OR TI((home OR homebased OR domicil $\left.{ }^{\star}\right)$ NEAR/3

(care* OR caring)) OR AB((home OR homebased OR domicil*) NEAR/3 nurs`) OR TI((home

OR homebased OR domicil $\left.{ }^{\star}\right)$ NEAR/3 nurse $\left.{ }^{\star}\right)$ OR AB((home OR homebased OR domicil ${ }^{\star}$ )

NEAR/3 (healthcare*)) OR TI((home OR homebased OR domicil $\left.{ }^{\star}\right)$ NEAR/3 (healthcare $\left.\left.{ }^{\star}\right)\right)$ OR

$\mathrm{AB}$ (nursing NEAR/3 outreach*) OR TI(nursing NEAR/3 outreach) OR AB(p*ediatric NEAR/3

ambulatory) OR TI(p*ediatric NEAR/3 ambulatory) OR AB(hospital NEAR/3 home) OR

TI(hospital NEAR/3 home) OR AB((nurs*) NEAR/3 (specialist* OR clinician* OR practitioner*))

or TI((nurs*) NEAR/3 (specialist* OR clinician* OR practitioner*))) AND (SU.EXACT("Infants"

OR "adolescents" OR "Children") OR AB(baby OR babies OR infant* OR toddler* OR child* 
OR preschool* OR preschool* OR teen* OR adolescen*) OR TI(baby OR babies OR infant*

OR toddler ${ }^{\star}$ OR child ${ }^{\star}$ OR preschool ${ }^{\star}$ OR preschool ${ }^{\star}$ OR teen ${ }^{\star}$ OR adolescen $\left.{ }^{\star}\right)$ ))

ClinicalTrials.gov All years, searched 10 February 2012

home nursing NOT "nursing home" | Child

ICTRP All years, searched 10 February 2012

home nursing and child*

WHAT'S NEW

\begin{tabular}{lll}
\hline Date & Event & Description \\
\hline 29 January 2013 & $\begin{array}{l}\text { New citation required and conclusions } \\
\text { have changed }\end{array}$ & Two new studies included. \\
\hline 30 October 2012 & New search has been performed & $\begin{array}{l}\text { Updated search. Two new studies found. 'Risk of bias' assess- } \\
\text { ments completed for all included studies. }\end{array}$ \\
\hline
\end{tabular}

\section{H I S T O R Y}

Protocol first published: Issue 3, 2003

Review first published: Issue 4, 2006

\begin{tabular}{lll}
\hline Date & Event & Description \\
\hline 9 November 2008 & Amended & Converted to new review format. \\
\hline 1 August 2006 & $\begin{array}{l}\text { New citation required and conclusions } \\
\text { have changed }\end{array}$ & Substantive amendment \\
\hline
\end{tabular}

\section{CONTRIBUTIONS OF AUTHORS}

All review authors contributed to the writing of the review.

\section{DECLARATIONSOF INTEREST}

Drs Woolfenden, Cooper and Piper co-ordinate or have co-ordinated ambulatory paediatric services in New South Wales, Australia. Dr Cooper is employed as a Staff Specialist Paediatrician at the Royal North Shore Hospital, Australia. Dr Parab is employed as a Staff Specialist Paediatrician at Wollongong in Illawarra Shoalhaaven Local Health District, Australia.

\section{N DEX TERMS}

\section{Medical Subject Headings (MeSH)}

Acute Disease [*nursing]; Chronic Disease [*nursing]; Home Care Services, Hospital-Based [*organization \& administration] [ ${ }^{\star}$ standards]; Home Nursing; Hospitalization [statistics \& numerical data]; Length of Stay [statistics \& numerical data]; Randomized Controlled Trials as Topic

\section{MeSH check words}

Adolescent; Child; Child, Preschool; Humans; Infant; Infant, Newborn 